Article

\title{
Anti-Osteoporosis Effect of Perilla frutescens Leaf Hexane Fraction through Regulating Osteoclast and Osteoblast Differentiation
}

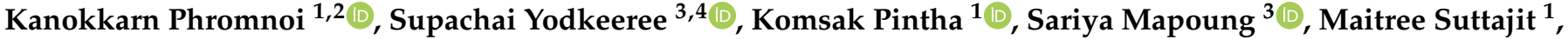 \\ Chalermpong Saenjum ${ }^{5,6, *}$ and Pornngarm Dejkriengkraikul ${ }^{3,4, *(D)}$
}

1 Division of Biochemistry, School of Medical Sciences, University of Phayao, Phayao 56000, Thailand; kanokkarn.ph@up.ac.th (K.P.); komsakjo@gmail.com (K.P.); maitree.suttajit@gmail.com (M.S.)

2 Unit of Excellence in Research to Develop Lanna Herbs against Osteoporosis, University of Phayao, Phayao 56000, Thailand

3 Department of Biochemistry, Faculty of Medicine, Chiang Mai University, Chiang Mai 50200, Thailand; yodkeelee@hotmail.com (S.Y.); srmapoung@gmail.com (S.M.)

4 Center for Research and Development of Natural Products for Health, Chiang Mai University, Chiang Mai 50200, Thailand

5 Department of Pharmaceutical Sciences, Faculty of Pharmacy, Chiang Mai University, Chiang Mai 50200, Thailand

6 Cluster of Excellence on Biodiversity-Based Economics and Society (B.BES-CMU), Chiang Mai University, Chiang Mai 50200, Thailand

* Correspondence: chalermpong.s@cmu.ac.th (C.S.); pornngarm.d@cmu.ac.th (P.D.)

\section{check for} updates

Citation: Phromnoi, K.; Yodkeeree, S.; Pintha, K.; Mapoung, S.; Suttajit, M.; Saenjum, C.; Dejkriengkraikul, P. Anti-Osteoporosis Effect of Perilla frutescens Leaf Hexane Fraction through Regulating Osteoclast and Osteoblast Differentiation. Molecules 2022, 27, 824. https://doi.org/ $10.3390 /$ molecules 27030824

Academic Editor: Francesco Cacciola

Received: 13 December 2021 Accepted: 25 January 2022

Published: 26 January 2022

Publisher's Note: MDPI stays neutral with regard to jurisdictional claims in published maps and institutional affiliations.

Copyright: (C) 2022 by the authors. Licensee MDPI, Basel, Switzerland. This article is an open access article distributed under the terms and conditions of the Creative Commons Attribution (CC BY) license (https:// creativecommons.org/licenses/by/ $4.0 /)$.

\begin{abstract}
Osteoporosis is the result of an imbalance in the bone-remodeling process via an increase in osteoclastic activity and a decrease in osteoblastic activity. Our previous studies have shown that Perilla frutescens seed meal has anti-osteoclastogenic activity. However, the role of perilla leaf hexane fraction (PLH) in osteoporosis has not yet been investigated and reported. In this study, we aimed to investigate the effects of PLH in osteoclast differentiation and osteogenic potential using cell-based experiments in vitro. From HPLC analysis, we found that PLH contained high luteolin and baicalein. PLH was shown to inhibit RANKL-induced ROS production and tartrate-resistant acid phosphatase (TRAP)-positive multi-nucleated osteoclasts. Moreover, PLH significantly downregulated the RANKL-induced MAPK and NF- $K B$ signaling pathways, leading to the attenuation of NFATc1 and MMP-9 expression. In contrast, PLH enhanced osteoblast function by regulating alkaline phosphatase (ALP) and restoring TNF- $\alpha$-suppressed osteoblast proliferation and osteogenic potential. Thus, luteolin and baicalein-rich PLH inhibits osteoclast differentiation but promotes the function of osteoblasts. Collectively, our data provide new evidence that suggests that PLH may be a valuable anti-osteoporosis agent.
\end{abstract}

Keywords: Perilla frutescens; osteoporosis; osteoclast; osteoblast; RANKL; TNF- $\alpha$

\section{Introduction}

Bone remodeling is mediated by a balance between osteoblastic bone formation and osteoclastic bone resorption. The disturbance of this balance results in several bone diseases, including arthritis, periodontitis, and osteoporosis [1,2]. Osteoporosis is a major worldwide health problem that affects mainly elderly and postmenopausal women. It leads to an increased risk of fractures and serious health concerns [3-5]. The current treatments for osteoporosis are anti-resorptive drugs (such as bisphosphonates, estrogen, selective estrogen receptor modulators, vitamin D, calcium, calcitonin, and denosumab) [6-8] and anabolic agents (abaloparatide and teriparatide) [9].

Various clinical studies recommend that osteoporotic treatments should improve the imbalance between bone formation and bone resorption at a cellular level [10]. Recently, 
there was a hypothesis relating to the possibility that combination therapy with antiresorptive and anabolic drugs would provide even greater benefits than either drug alone [11]. However, patients treated with these inhibitors encountered undesirable negative side effects [12]. Therefore, an identification of natural products is needed. In addition, if it is an antiresorptive and anabolic natural compound in one, it will be beneficial to osteoporosis patients and the health conscious.

Osteoclasts are differentiated from monocyte/macrophage lineage cells in that they are characterized by their multi-nucleated cellular morphology and high tartrate-resistant acid phosphatase (TRAP) expression. Osteoclasts are developed upon induction by a macrophage colony-stimulating factor (M-CSF) and the receptor for activation of nuclear factor-kappa B ligand (RANKL)/osteoprotegerin ligand (OPGL), which are secreted by osteoblasts [13]. The binding of RANKL to the RANK receptor recruits the TNF receptorassociated factor (TRAF) family molecules, which sequentially induces the production of oxidative stress such as reactive oxygen species (ROS) and activates the nuclear factor kappa $\mathrm{B}$ (NF-KB) and the mitogen-activated protein kinase (MAPK) pathways [14]. This leads to the activation of transcription factors such as nuclear factor of activated T cells c1 (NFATc1), which stimulates osteoclast development by upregulating downstream osteoclastic target genes, such as matrix metalloproteinase-9 (MMP-9) $[15,16]$.

Osteoblasts are mononuclear cells that are differentiated from mesenchymal stem cells due to the activation of various transcription factors [17]. The Runt-related transcription factor 2 (Runx2) induces the expression of osteogenic genes, including type I collagen (COL1), bone sialoprotein (BSP), osteopontin (OPN), and osteonectin (OSN) especially, and alkaline phosphatase (ALP) and MMP-2, which are involved in the maturation step of osteoblasts [18-21]. In addition, the differentiation of osteoblasts is regulated by tumor necrosis factor- $\alpha$ (TNF- $\alpha$ ), which has an inhibitory influence on bone formation through the inhibition of osteoblast differentiation and the induction of osteoblast apoptosis [22].

Even though novel drugs for osteoporosis treatments that act on different molecular targets of osteoporosis have been developed [23], searching for medicinal plants to rectify the imbalance of bone metabolism is also a great potential alternative approach. Various medicinal plants were used in Thai traditional medicinal remedies for osteoporosis prevention and treatment, such as Pueraria mirifica, Cissus quadrangularis Linn, Zingiber montanum, and Sesamum indicum $[24,25]$. One of the potential plant candidates, Perilla frutescens L., has been reported to have osteoclastogenic protection properties and has been used in northern Thai traditional remedies [26].

P. frutescens L., known as perilla, or Nga-Mon in Thai, is an herb that belongs to the mint family, and is traditionally grown in Thailand and many Asian countries [27]. The perilla leaves are edible and nutritious, and also used as a spice and a food decoration or flavoring [28-30]. Several studies indicated that perilla leaf extracts exhibited antioxidant and anti-inflammatory [31,32], antitumor [33,34], anti-diabetic [35], anti-nociceptive [36], anti-tuberculosis, and antimicrobial [37] activities. Recently, phytochemical studies have shown that water extract of perilla leaves contains rosmarinic acid, luteolin, baicalin, rutin, catechin, apigenin, gallic acid, chlorogenic acid, L-epicatechin, baicalein, and other flavonoids $[30,38]$. Nevertheless, phytochemical compounds in the perilla leaf hexane fraction (PLH) had never been reported. Therefore, in this study, we evaluated the active compounds in PLH.

Numerous flavonoids, including rutin, hesperidine, genistein, daidzein, and anthocyanins, have demonstrated beneficial effects for bone health in various targets and mechanisms of osteoporosis prevention and treatment [39]. Interestingly, a synthetic flavonoid, luteolin, has been shown to inhibit RANKL-induced osteoclastogenesis through the suppression of activation of activating transcription factor 2 (ATF2), downstream of p38 MAPK and NFATc1 expression [40]. Moreover, purified luteolin promoted osteoblastic proliferation and differentiation by attenuating oxidative stress and regulating the ratio of osteoprotegerin/RANKL and induced various osteogenic markers [41]. It is reported that synthetic baicalein inhibits bone resorption by inducing the apoptosis of mature osteoclasts [42], and 
that purified baicalein promotes osteoblastic differentiation by inducing the transcripts and protein expressions of OSX, COL-1, and RUNX-2 through MAPK and the Wnt/ $\beta$-catenin pathway [43]. Furthermore, our previous studies found that rosmarinic acid-enriched perilla seed meal showed anti-osteoclastogenesis in the RAW264.7 cell line [26]. However, the role of luteolin and baicalein-rich PLH in osteoporosis has not been investigated and reported yet.

The aim of this study was to investigate the effect of PLH on osteoclastogenic activity and osteogenic potential. We established the effect of PLH on RANKL-induced osteoclast differentiation and the underlying mechanisms. Moreover, the effects of PLH on osteogenic potential without or with TNF- $\alpha$ treatment were investigated by measuring the cell proliferation, ALP, and MMP-2 activities.

\section{Results}

\subsection{Determination of Active Compounds in PLH}

The quantification mount of phytochemical constituents of PLH was analyzed by reversed-phase HPLC. The PLH compared to the mixed standard demonstrated that luteolin and baicalein were dominant compounds, followed by apigenin, kaempferol, quercetin, rosmarinic acid, and rutin as shown in Figure 1 and Table 1 . The separation of mixed compounds in PLH from the hydrophobic stationary phase HLPC column corresponded to the $\log p$-value of each compound, as shown in Table 1.

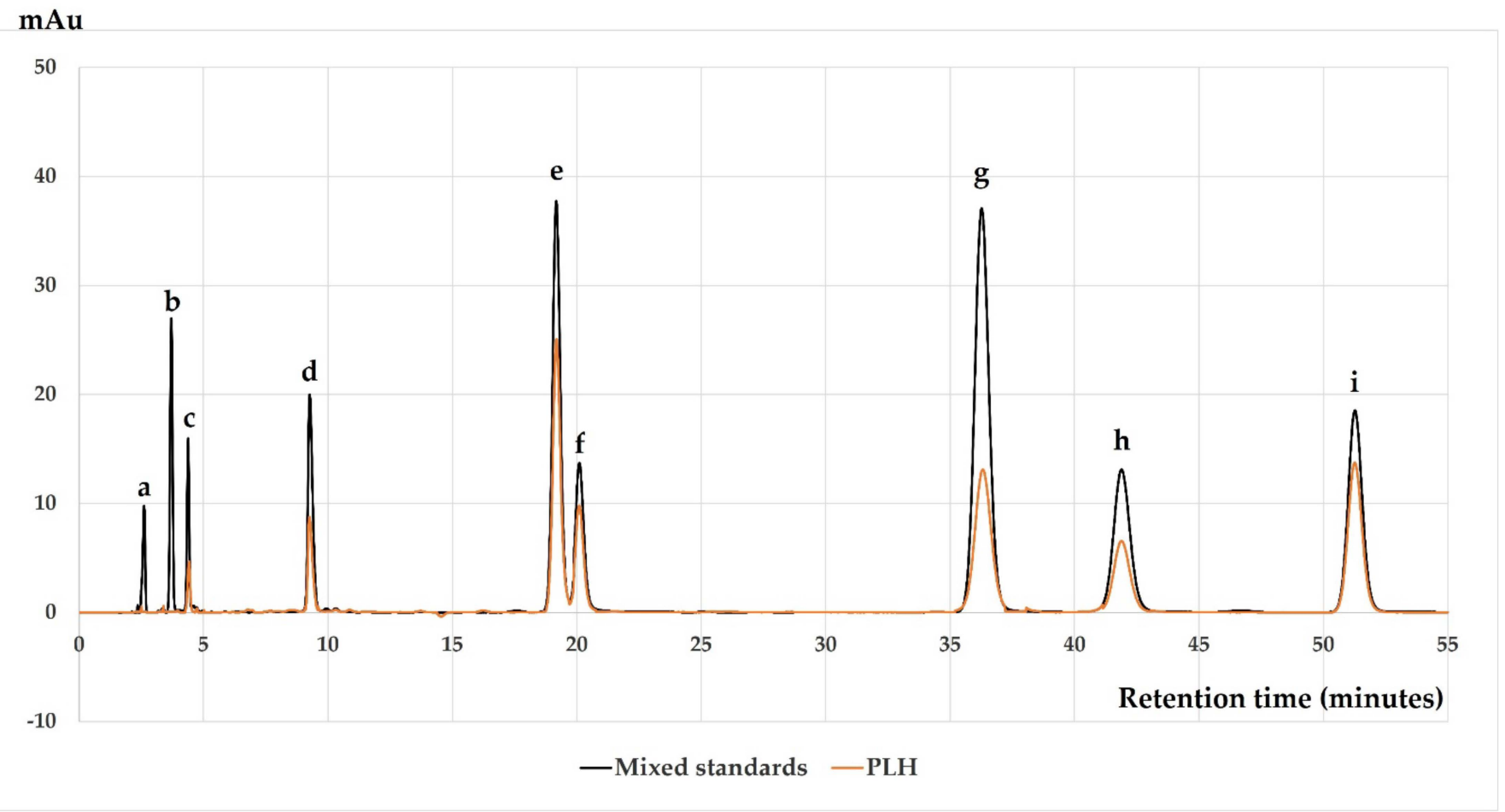

Figure 1. HPLC chromatograms of mixed standard and PLH. The peaks reveal (a) gallic acid, (b) caffeic acid, (c) rutin, (d) rosmarinic acid, (e) luteolin, (f) quercetin, (g) apigenin, (h) kaempferol, and (i) baicalein. The mobile phase consisted of $30 \%$ acetonitrile in $0.1 \%$ acetic acid and de-ionized water at a flow rate of $1.0 \mathrm{~mL} / \mathrm{min}$. The content peaks were detected by a UV detector at $325 \mathrm{~nm}$.

\subsection{Effect of PLH on Cell Viability}

The cytotoxicity effects of PLH against the macrophage, RAW264.7 cells and osteoblastlike, MG-63 and SAOS-2 cells were examined by MTT assay. As shown in Figure 2, there was no significant decline in cell viability at concentrations ranging lower than $100 \mu \mathrm{g} / \mathrm{mL}$ at $48 \mathrm{~h}$ treatment compared to untreated cells. At least three non-cytotoxic dosages of the PLH $(12.5,25$, and $50 \mu \mathrm{g} / \mathrm{mL})$ were selected for further experiments. 
Table 1. The HPLC analysis and Log $p$-values of the phytochemical constituents of PLH, ranking from the highest to the lowest amount.

\begin{tabular}{ccc}
\hline \multirow{2}{*}{ Compounds } & Amount & Log $p$ \\
\cline { 2 - 3 } & $\mathbf{( m g / g}$ Fraction) & Octanol/Water \\
\hline Luteolin & $139.19 \pm 2.84^{\mathrm{a}}$ & 2.53 \\
Baicalein & $70.09 \pm 2.32^{\mathrm{b}}$ & 3.59 \\
Apigenin & $39.51 \pm 1.60^{\mathrm{c}}$ & 3.02 \\
Kaempferol & $23.69 \pm 1.51^{\mathrm{d}}$ & 3.11 \\
Quercetin & $16.06 \pm 0.79^{\mathrm{e}}$ & 1.82 \\
Rosmarinic acid & $9.97 \pm 0.47^{\mathrm{f}}$ & 1.82 \\
Rutin & $5.22 \pm 0.39 \mathrm{~g}$ & -1.13 \\
Caffeic acid & ND & 1.15 \\
Gallic acid & ND & 0.7 \\
\hline
\end{tabular}

Means with different letters $(\mathrm{a}, \mathrm{b}, \mathrm{c}, \mathrm{d}, \mathrm{e}, \mathrm{f}$, and $\mathrm{g})$ are significantly different $(p<0.05)$. ND = not detectable.
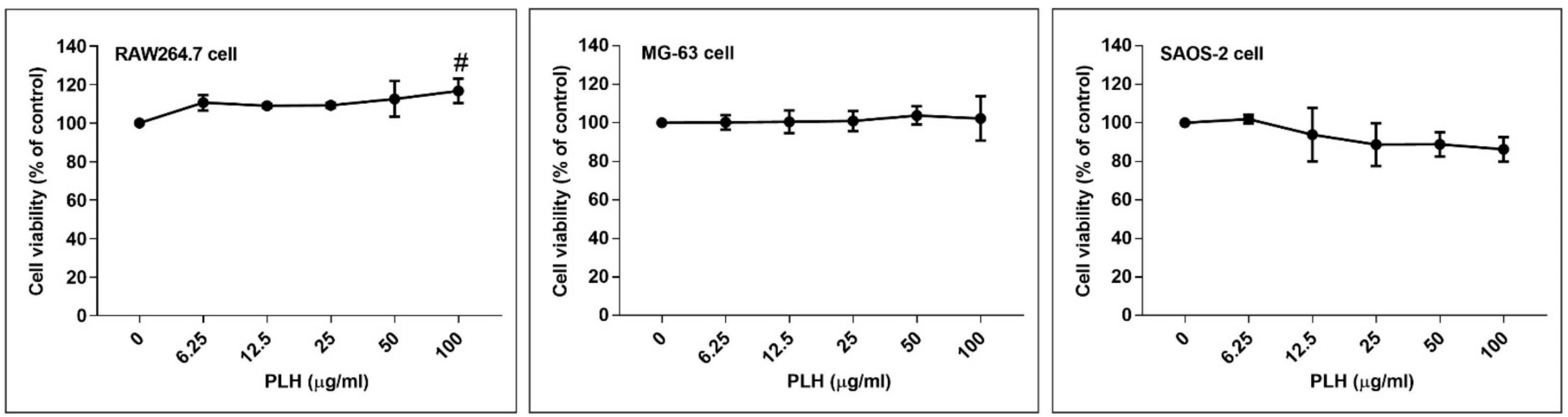

Figure 2. Viability of RAW264.7, MG-63, and SAOS-2 cells incubated with various concentrations of PLH using MTT assay. Each value is the mean \pm SD of three independent experiments. \# $p<0.05$ vs. control (0).

\subsection{Effect of PLH on ROS Production in RAW264.7 Cells}

Monocyte-/macrophage-like cells, RAW264.7 cells, can differentiate into osteoclasts in the presence of RANKL. They are also evaluated as a great model for in vitro osteoclast differentiation studies [44,45]. RANKL induces intracellular ROS generation, which leads to the activation of osteoclast differentiation $[35,46,47]$. Therefore, the effect of PLH on RANKL-induced ROS production was determined. The results show that ROS production was enhanced through RANKL stimulation up to $143.33 \pm 0.17 \%$ of the control. However, the induced formation of intracellular ROS was significantly attenuated by the treatment of PLH, the same as NAC and vitamin C $(p<0.001)$ (Figure 3). Thus, we can hypothesize that the neutralization of ROS by PLH may subsequently prevent osteoporosis.

\subsection{Effects of PLH on RANKL-Mediated TRAP-Positive Osteoclast-Like Cell Formation In Vitro}

In our study, RAW264.7 cells were cultured in the presence of $100 \mathrm{ng} / \mathrm{mL}$ RANKL and various concentrations of PLH $(0,12.5,25$, and $50 \mu \mathrm{g} / \mathrm{mL})$. After six days of incubation, the multinucleated TRAP-positive cells were stained and visualized through microscopy. TRAP activity was determined using a TRAP solution assay. Luteolin and baicalein, key active ingredients of PLH, were parallel evaluated in the same experiment. Figure 4A,B illustrates that RANKL treatment induced the differentiation of RAW264.7 cells into osteoclast-like multinucleated (three or more nuclei) cells. 


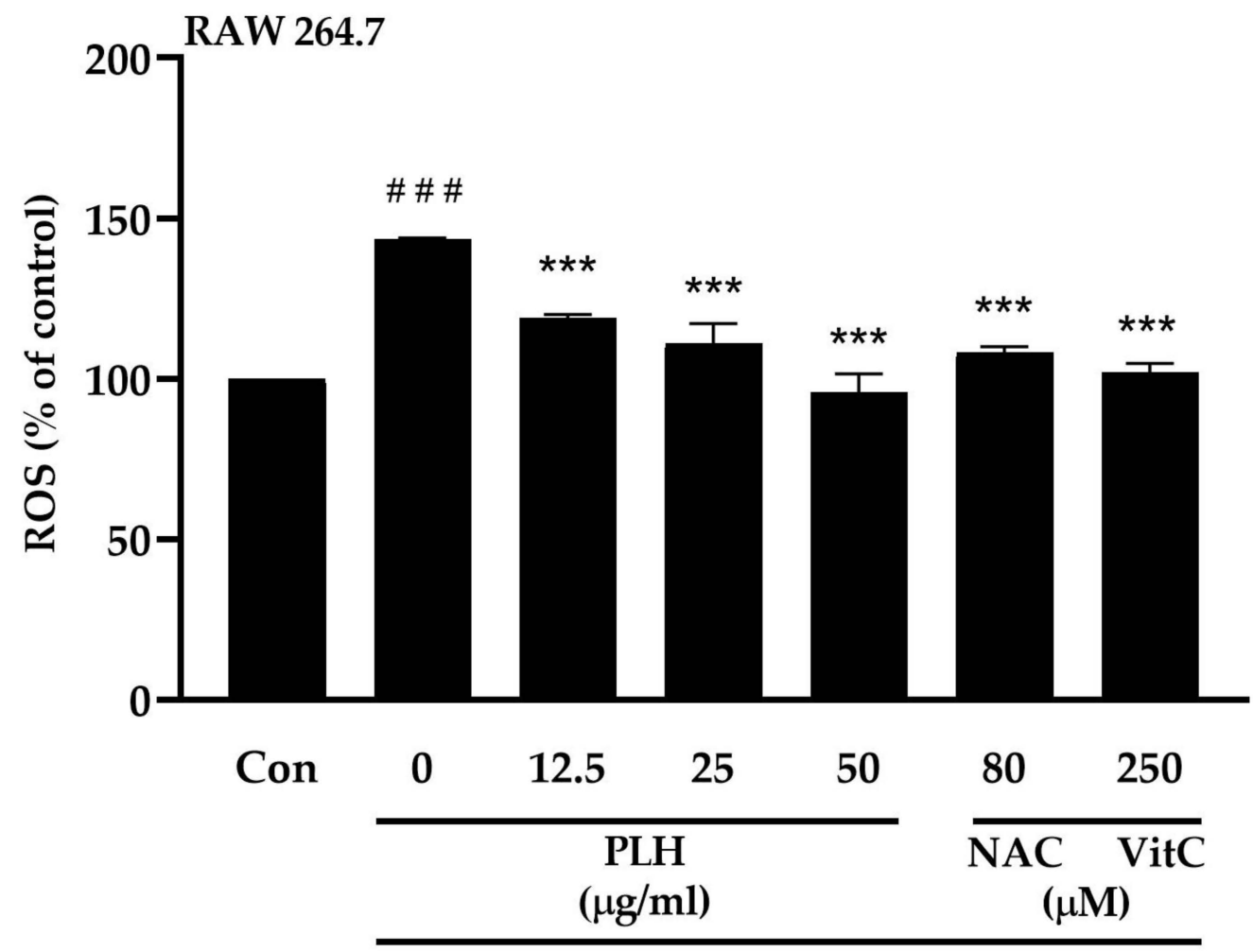

RANKL (100 ng/ml)

Figure 3. RANKL-induced ROS production by PLH treatment. Untreated cells were used as a negative control (Con). N-acetylcysteine $80 \mu \mathrm{M}$ (NAC) and vitamin C $250 \mu \mathrm{M}$ (Vit C) were used as positive controls. Each value is the mean $\pm \mathrm{SD}$ of three independent experiments, \#\#\# $p<0.001$ vs. control (Con), ${ }^{* * *} p<0.001$ vs. RANKL treatment (0).

In contrast, when the cells were treated with PLH, the number of multinucleated cells was remarkably suppressed in a dose-dependent manner. Luteolin at $7 \mu \mathrm{g} / \mathrm{mL}$ and baicalein at $3.5 \mu \mathrm{g} / \mathrm{mL}$, calculated to be equivalent to $50 \mu \mathrm{g} / \mathrm{mL}$ of PLH, similarly suppressed RANKL-induced osteoclast differentiation. TRAP activity was also quantitatively examined: It was found that the activity was increased up to $159.15 \pm 7.9 \%$ after treatment with RANKL compared to the control. PLH significantly inhibited RANKL-induced TRAP activity in a dose-dependent manner, similar to luteolin and baicalein treatment $(p<0.001)$ (Figure 4C). These results indicate that luteolin and baicalein-enriched PLH can exhibit a potent inhibitory effect on RANKL-induced osteoclast formation.

\subsection{Effect of PLH on Osteoclastic-Specific Protein Expression}

MMP-9 is the most abundant gelatinolytic enzyme in osteoclasts, which has a significant role in bone matrix degradation and resorption $[48,49]$. MMP-9 can be used as one alternative way to measure resorption activity, as previously described elsewhere [50,51]. Moreover, MMP-9 secretion can be induced by RANKL after long-term incubation [52,53]. To further identify the inhibitory effect of PLH on RANKL-induced osteoclastogenesis, we investigated the expression of this osteoclast-specific protein marker, MMP-9, using gelatin zymography assays. Figure 5 illustrates that MMP-9 activity was enhanced up to $328.83 \pm 36.88 \%$ after RANKL incubation for three days. However, the RANKL-induced MMP-9 levels was significantly decreased after PLH treatment in a dose-dependent manner $(p<0.001)$. Collectively, these results suggested that PLH suppressed osteoclast differentiation and function. 
(A)

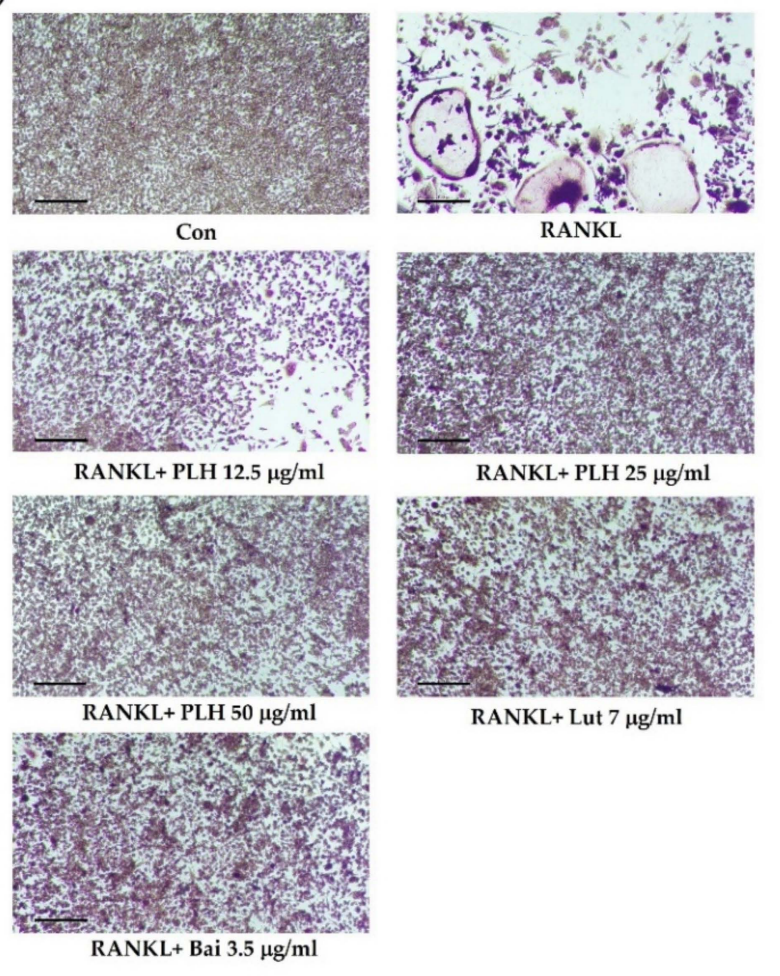

(B)

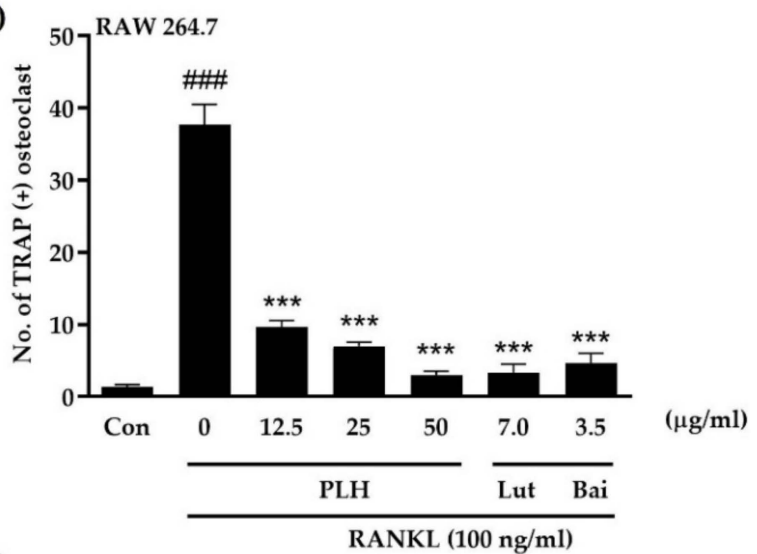

(C)

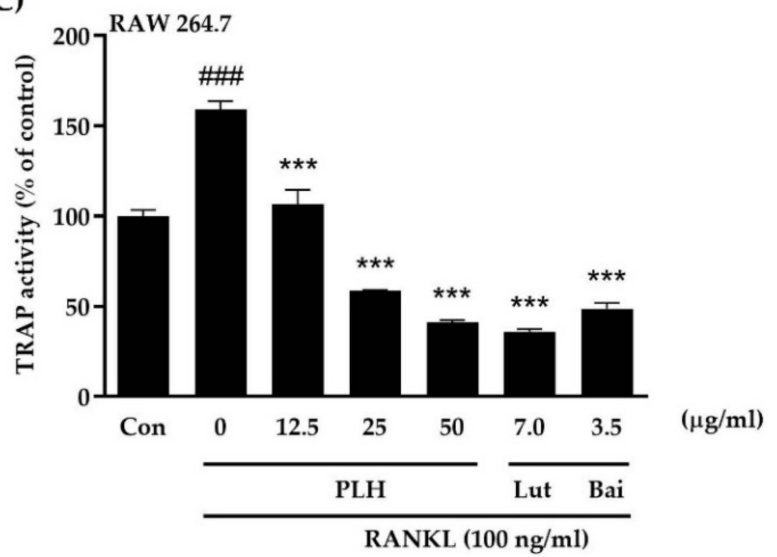

Figure 4. RANKL-induced TRAP-positive osteoclast-like cell formation by PLH treatment. (A) Osteoclast differentiation: Multinucleated osteoclasts were visualized in $100 \times$ magnification under light microphotography. Scale bars, $100 \mathrm{~mm}$. (B) TRAP-positive multinucleated cells were counted as osteoclasts. (C) TRAP activity was measured using the TRAP solution assay. Luteolin (Lut) and baicalein (Bai) were active compounds of PLH. Each value is the mean \pm SD of three independent experiments. \#\#\# $p<0.001$ vs. control (Con), ${ }^{* * *} p<0.001$ vs. RANKL treatment $(0)$.

\subsection{Effects of PLH on RANKL-Induced NF- $K B, M A P K$, and NFATc1 during Osteoclast Differentiation}

The combination of RANKL and RANK leads to the activation of downstream cellsignaling pathways, such as the NF- $\mathrm{KB}$ and MAPK pathways [54-57], which, in turn, results in the activation of the critical osteoclast differentiation-related transcription factors, such as NFATc1. This leads to the expression of downstream targets, including TRAP, cathepsin $\mathrm{K}$, and MMP-9. Thus, agents suppressing these signals may inhibit osteoclastogenesis and bone loss. It would be interesting to discover whether PLH can inhibit osteoporosis through the NF- $\mathrm{kB}, \mathrm{MAPK}$, and NFATc1 pathways. Due to the phosphorylation of NF- $\mathrm{B}$ (p50/p65), which plays a significant role in the stimulation of its pathway, we focused on NF- $\mathrm{BB}$ phosphorylation using Western blotting analysis. Figure 6A,B demonstrates that the phosphorylation of p65 was evidently increased after RANKL stimulation. However, the PLH treatments at various concentrations remarkably impaired the RANKL-induced signaling molecules to the control level. As the phosphorylation of p38 and JNK also plays a vital role in RANKL-induced osteoclastogenesis [58], the inhibitory effect of PLH on p38 and JNK activation was also studied. The results show that the phosphorylation of p38 and JNK immensely increased when treated with RANKL. In contrast, the PLH treatment significantly downregulated the phosphorylation of p38 and JNK. Additionally, similar to the results of NF- $\mathrm{B}$ and MAPK, PLH can abrogate RANKL-induced NFATc1. 


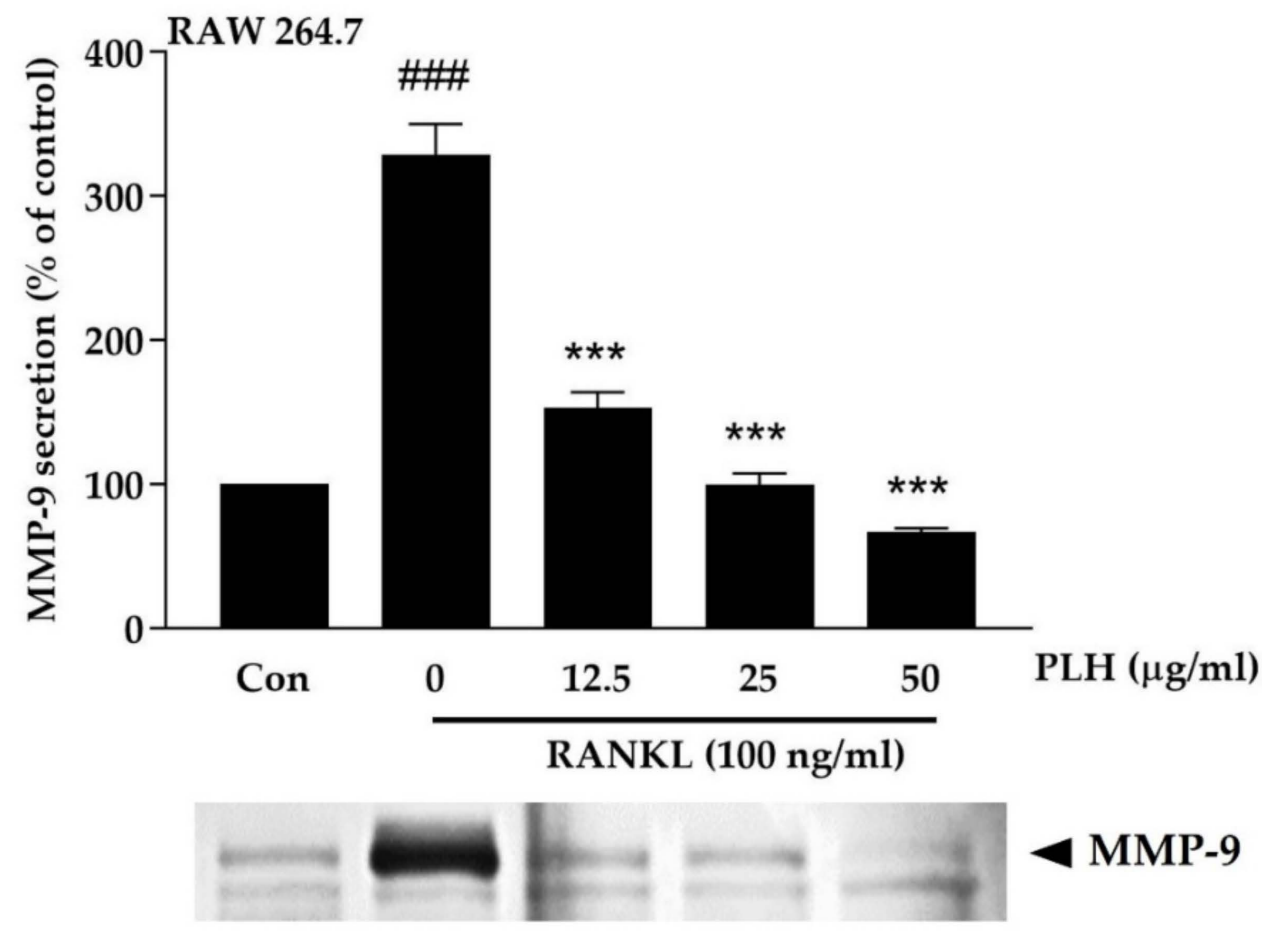

Figure 5. RANKL-induced MMP-9 expression by PLH treatment. RAW264.7 cells were co-treated with RANKL and PLH for $72 \mathrm{~h}$. Culture supernatants were collected, and the secretion of MMP-9 was analyzed using gelatin zymography. Each value is the mean $\pm \mathrm{SD}$ of three independent experiments. \#\#\# $p<0.001$ vs. control (Con), ${ }^{* * *} p<0.001$ vs. RANKL treatment (0).

\subsection{Effect of PLH on Osteogenic Potential}

Besides osteoclastogenesis, we also studied osteoblast function using MG-63 and SAOS-2 cells [59-63] by measuring the activities of ALP and MMP-2 as important markers for the early and late differentiation of osteoblast cells, respectively [64]. ALP can hydrolyze inorganic pyrophosphate, which is a naturally occurring inhibitor of mineralization [65], whereas MMP-2 can shed the immune costimulatory molecule B7-H3 from the cell membrane of osteoblasts, leading to bone mineralization [66]. Figure 7A,B shows the increase in ALP activity in both MG-63 and SAOS-2 osteoblast cells after PLH treatment for $72 \mathrm{~h}$, consistent with luteolin and baicalein treatment, which are the main compounds in PLH. In contrast, Figure 7C,D shows that PLH did not affect MMP-2 levels in either MG-63 or SAOS-2 cells compared to the control. Based on these results, PLH is able to induce the differentiation of early-stage osteoblasts through ALP activation and is not associated with MMP-2.

\subsection{Effects of PLH on TNF- $\alpha$-Suppressed Osteogenic Potential}

The activity of osteoblasts is regulated by the inflammatory cytokine TNF- $\alpha$, which induces osteoblast apoptosis and inhibits osteoblast differentiation [67-69]. Therefore, any compounds that inhibit TNF- $\alpha$-suppressed cell viability and differentiation may prevent bone diseases. The osteoprotective effects of PLH on TNF- $\alpha$-treated osteoblasts were elucidated using MTT and ALP activity assays. As demonstrated in Figure 8A,B, PLH significantly restores TNF- $\alpha$-suppressed osteoblast-like cell viability. 
(A)

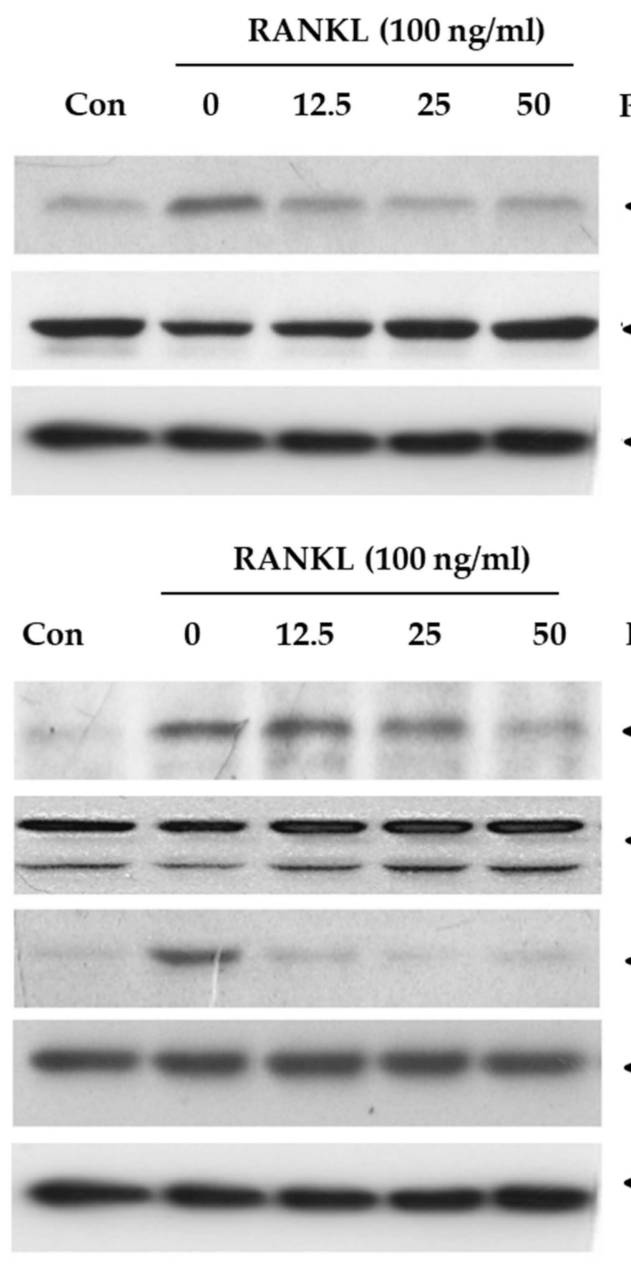

PLH $(\mu \mathrm{g} / \mathrm{ml})$

p-JNK

JNK

p-p38

p38

$\beta$-actin

RANKL (100 ng/ml)

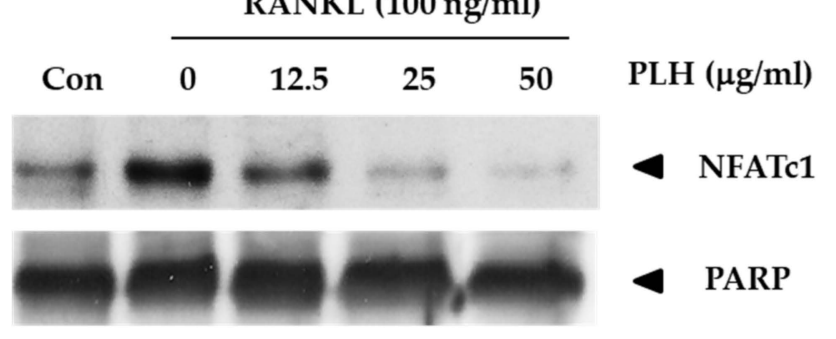

(B)
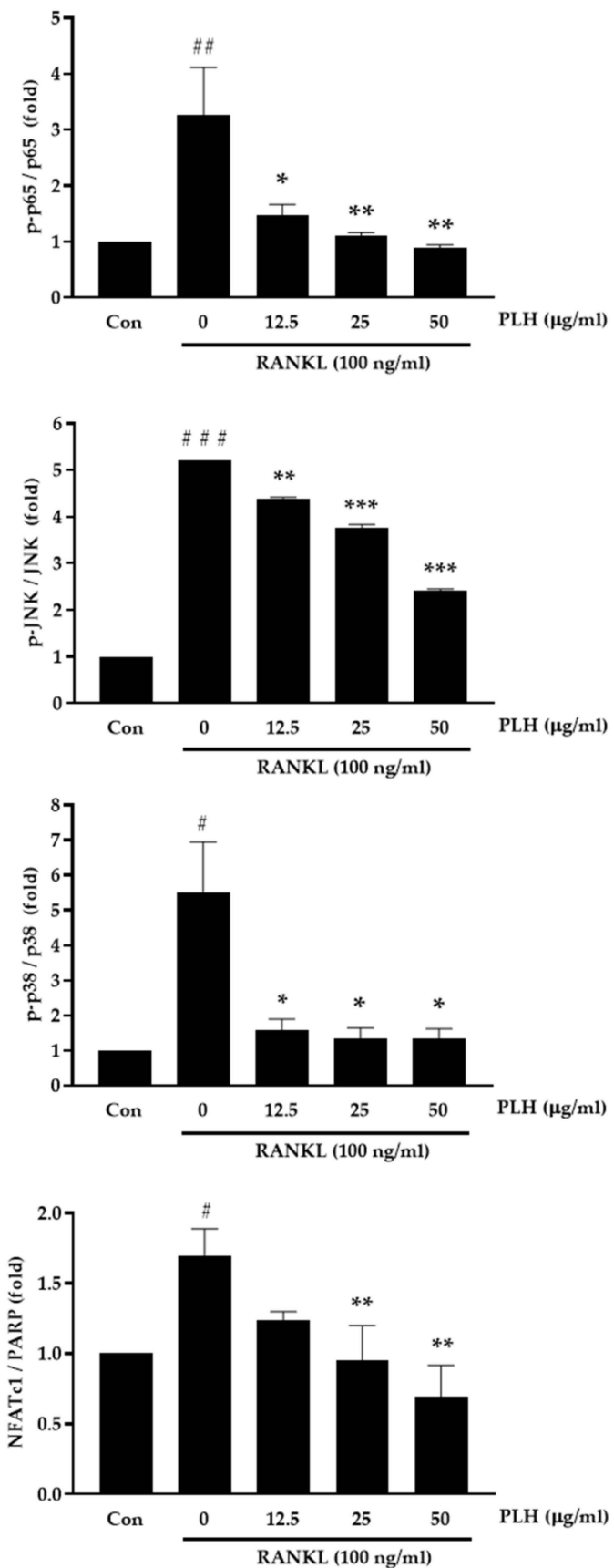

Figure 6. RANKL-induced NF- $\mathrm{B}, \mathrm{MAPK}$, and NFATc1 signaling by PLH treatment. RAW 264.7 cells were pretreated with PLH $(0,12.5,25$, and $50 \mu \mathrm{g} / \mathrm{mL})$ for $12 \mathrm{~h}$ and then exposed to RANKL (100 ng/mL) for $10 \mathrm{~min}$. The whole cell extract was used to determine phosphorylation levels of NF- $\mathrm{B}$, JNK, and p38. The nuclear extracts were prepared and NFATc1 expression was analyzed. (A) Protein expression of NF- $\mathrm{BB}, \mathrm{MAPKs}$, and NFATc1 was measured using the Western blot method. (B) The expression of p-p65, p-JNK, p-p38, and NFATc1 was normalized to total p65, JNK, p38, and PARP, respectively. Each value is the mean \pm SD of three independent experiments. \#\#\# $p<0.001$; \#\# $p<0.01$; \# $p<0.05$ vs. control (Con), ${ }^{* * *} p<0.001$; $^{* *} p<0.01{ }^{*} p<0.05$ vs. RANKL treatment (0). 
(A)

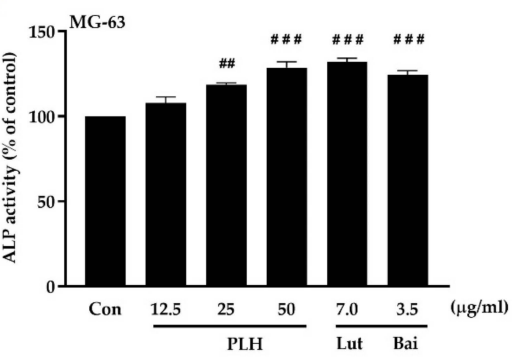

(C)

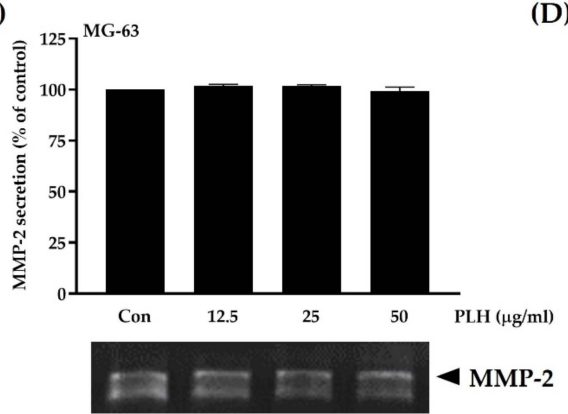

(B)

(D)
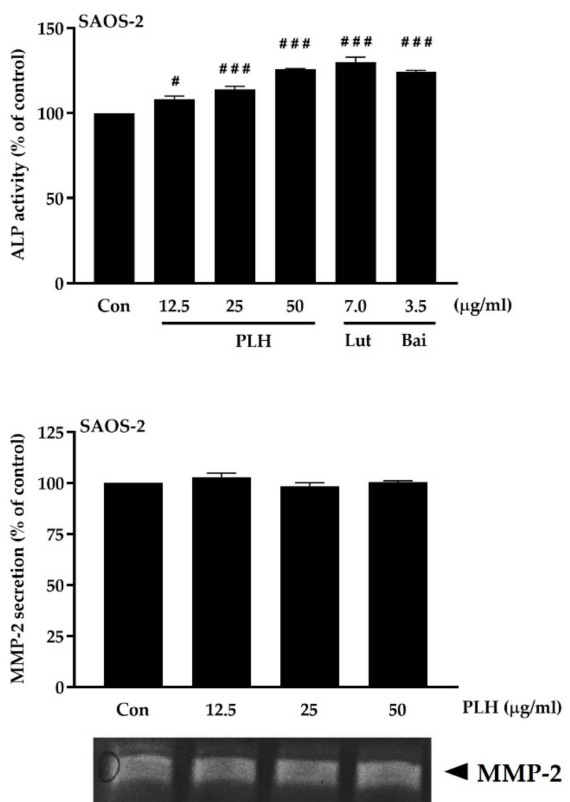

Figure 7. ALP activity and MMP-2 expression in osteoblast-like cells by PLH treatment. (A) MG63- and (B) SAOS-2-treated cells were tested for ALP using colorimetric analysis. (C) MG-63 and (D) SAOS-2 culture supernatants were collected and analyzed for MMP-2 secretion by gelatin zymography. Luteolin (Lut) and baicalein (Bai) were active compounds of PLH. Each value is the mean \pm SD of three independent experiments. \#\#\# $p<0.001$; \#\# $p<0.01$; \# $p<0.05$ vs. control (Con).

(A)

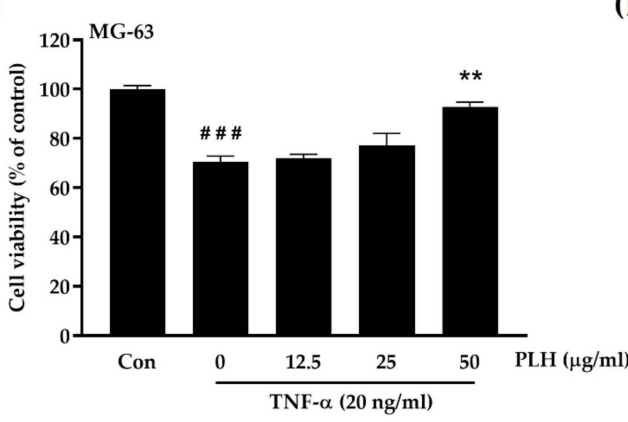

(C)

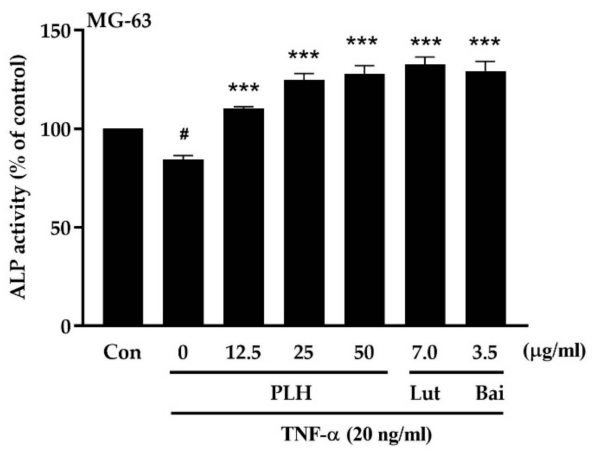

(B)

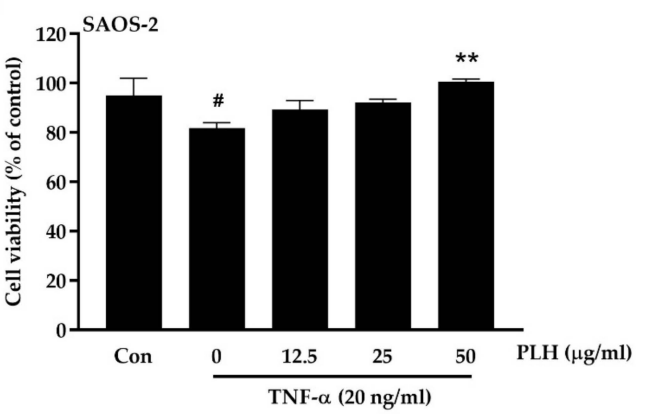

(D)

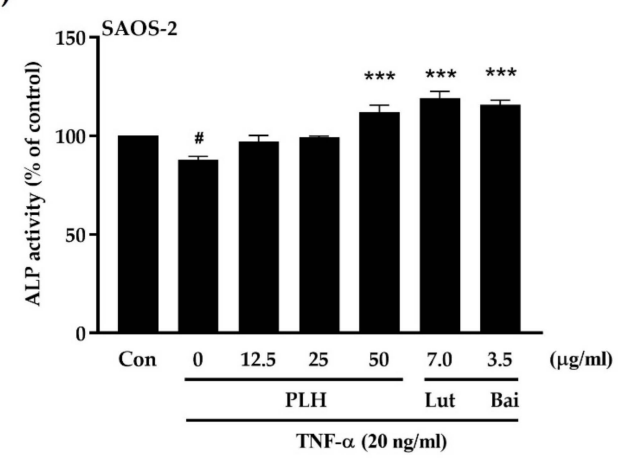

Figure 8. PLH restored TNF- $\alpha$-suppressed osteogenic potential. Cells were co-treated with TNF- $\alpha$ $(20 \mathrm{ng} / \mathrm{mL})$ and various concentrations of PLH $(0-50 \mu \mathrm{g} / \mathrm{mL})$ for $48 \mathrm{~h}$ (cell proliferation) and $72 \mathrm{~h}$ (ALP activity). (A) MG-63- and (B) SAOS-2-treated cells were measured for viability using MTT assay. (C) MG-63- and (D) SAOS-2-treated cells were tested for ALP using colorimetric analysis. Each value is the mean $\pm \mathrm{SD}$ of three independent experiments. \#\#\# $p<0.001$; \# $p<0.05$ vs. control (Con), *** $p<0.001 ;{ }^{* *} p<0.01$ vs. TNF- $\alpha$ treatment (0). 
In addition to TNF decreased cell viability, TNF- $\alpha$ treatment also resulted in a significant reduction in ALP activity in MG-63 and SAOS-2 cells (Figure 8C,D). The reduction activity was ameliorated in response to PLH treatments, including luteolin and baicalein treatments, which were used as positive controls, suggesting that PLH was able to significantly protect osteoblasts from TNF- $\alpha$-suppressed osteogenic potential. Based on these results, PLH is able to induce osteoblasts.

\section{Discussion}

Osteoporosis has been specified as a metabolic disorder characterized by an imbalance in the bone-remodeling process. The resorption of bone is increased without adequate new bone formation, inducing osteoblast apoptosis and suppression of osteoclast apoptosis [70]. As a result of the high costs and side effects of anti-osteoporotic or anabolic chemical agents, the search for natural products that would allow for more affordable treatment of this disease, with more marginal side effects, has become essential [6]. The focus of this study was perilla leaves, less commonly eaten than perilla seeds, which we suggest may have value as an alternative food in our diets.

After the solvent partition isolation technique was used, we evaluated the number of active compounds in the other fraction by using HPLC. We found that each fraction contained different bioactive compounds. The main bioactive compounds contained in leaf water fraction were rutin, caffeic acid, and gallic acid. The leaf ethyl acetate fraction indicates that rosmarinic acid was the major active compound. Meanwhile, luteolin and baicalein were the major active compounds in the leaf hexane fraction. The leaf hexane fraction showed the highest inhibitory effect on ROS production compared to the water, dichloromethane, and ethyl acetate fractions (data not shown). Therefore, we next focused on the hexane fraction. The PLH contains the phytochemical compounds listed in Table 1, and most compounds can be obtained from the hexane fraction. This is partitioned from crude ethanolic extract, which offers a greater yield than those partitioned from water extract, so it is more advantageous.

Phytochemical constituents from the HPLC analysis showed that the PLH contained high amounts of luteolin and baicalein but less apigenin, kaempferol, quercetin, rosmarinic acid, and rutin. Importantly, the Log $p$-value is the logarithm of the partition coefficient between the concentrations of a solute in immiscible binary-phase solvents when one of the solvents is water and the other is octanol, which measures for the lipophilicity or hydrophobicity of each compound. As shown in Table 1, baicalein had the highest $\log p$, followed by kaempferol, apigenin, luteolin, quercetin, rosmarinic acid, caffeic acid, and rutin. According to the procedure of PLH, which is partitioned from crude ethanolic extract, luteolin and baicalein are the major components. Pintha et al. reported that luteolin was a major constituent in crude perilla leaf ethanolic extract [33]. Additionally, Wang et al. reported that rosmarinic acid, rutin, luteolin, and catechin were the dominant components in the ethyl acetate fraction that was partitioned from crude ethanolic leaf extract [71]. In the current study, we propose that luteolin and baicalein were distributed from the crude ethanolic extract, which was dissolved in deionized water, to hexane due to a high value of $\log p$ during the solvent partition process.

In addition, studies done on the active ingredients of PLH, luteolin and baicalin, have shown that luteolin can actually inhibit osteoclast differentiation and defense against bone loss, and help in the prevention of osteoporosis [72]. Luteolin also suppresses the mitochondrial apoptosis of osteoblasts via inhibition of STAT1 activity [73]. Moreover, baicalin was shown to be therapeutic for osteoclast-related bone diseases through the inhibition of the NF- $\kappa$ B and ERK pathways [74]. Baicalein can stimulate osteoblast differentiation via the activation of the mTORC1 signaling pathways, including the P-S6K1 and P-4E/BP1 transcription factors [75].

RANKL signaling initiates enhanced osteoclast formation and bone resorption. As such, inhibiting osteoclast formation could be a valuable form of treatment for pathological bone loss [76]. Physiologically, ROS plays an important role in the remodeling process, 
whereby overproduction of ROS by osteoclasts accelerates bone resorption [77]. Our study demonstrated a high production rate of ROS in RAW264.7 cells after RANKL stimulation was scavenged using PLH treatment. The strong ROS inhibition of hexane extract may suggest that hexane, which has a polarity index amount of $0(P I=0)$, was able to extract lipophilic compounds that can diffuse easily through the lipid-bilayer membrane [78]. Thus, lipophilic compounds may enhance cellular uptake and cellular antioxidant effects, such as ROS generation [79]. It is known that RANKL stimulation upregulates the expression of TRAP and MMP-9, important proteins in osteoclasts, to degrade the organic bone matrix [80-82]. Our results indicate that PLH inhibited RANKL-induced osteoclast formation and differentiation from macrophage to multinucleated cells by TRAP staining and colorimetric method, consistent with luteolin and baicalein treatment; these are the main active compounds of PLH. Moreover, the results from gelatin zymography further reveal that the anti-resorption effects of PLH were accompanied by diminished expression levels of MMP-9.

NF-kB, MAPK, and NFATc1 signaling pathways are known to play a significant role in osteoclast differentiation. Binding of RANKL to RANK leads to the recruitment of TRAP6 [83] and activates NF- $\mathrm{BB}$ and MAPK [84], leading to the activation of NFATc1, which in turn results in the expression of downstream targets, including TRAP and MMP-9 [85]. A specific inhibitor of p38 MAPK suppressed RANKL-mediated osteoclast differentiation in RAW 264.7 cells [86], and osteoclast precursor cells derived from JNK1-lacking mice exhibited reduced osteoclast differentiation [87]. p38 affects early osteoclastogenesis and plays an important role in the expression of cathepsin K [88], which JNK-deficient rats are unable to differentiate into osteoclasts [87]. RANKL also activates the classical NF- $\mathrm{B}$ pathway after degradation of I $\mathrm{B}$ through a ubiquitin/proteasome pathway. NF- $\kappa \mathrm{B}$ is subsequently phosphorylated and translocated from the cytoplasm into the nucleus [89]. A previous study demonstrated that selective inhibition of NF- $\mathrm{B}$ activation blocked osteoclastogenesis and prevented inflammatory bone destruction in vivo and in vitro [56]. To investigate the molecular mechanisms associated with the inhibitory effects of PLH, Western blotting was used. The present study confirmed that PLH suppressed osteoclast differentiation by inhibition of the phosphorylation of JNK, p38, and p65, as well as the expression of NFATc1, and subsequently reduced the expression of TRAP and MMP-9.

Oxidative stress and ROS are also fundamental in osteoblasts, and many previous studies verified the bone anabolic activities of natural products by using these targets [90-93]. Additionally, osteoblast studies also have also looked at alternative pathways such as Wnt/ $\beta$ catenin to investigate the impairment or the amelioration of osteogenic potential [94-96].

However, in our preliminary studies of osteogenic potential, we also investigated how the regulation of ALP and MMP-2 plays a significant role in the early and late differentiation of osteoblast cells, respectively. Therefore, the focus was on whether PLH could moderate ALP and MMP-2 activation. Our findings showed that PLH significantly increased ALP activity both with and without TNF- $\alpha$ stimulation. However, PLH did not affect the MMP2 levels. Moreover, PLH could restore TNF- $\alpha$-suppressed osteogenic potential, maybe as a result of its anti-apoptotic effect. These results suggest that the potential of PLH may be induced pro-anabolic activities. The physiopathological framework, including the intracellular pathway of osteogenic molecules on PLH, requires further study.

\section{Materials and Methods}

\subsection{Reagents and Chemicals}

Recombinant mouse soluble RANKL was obtained from R\&D Systems (Minneapolis, MN, USA). Dulbecco's Modified Eagle Medium (DMEM), $\alpha$-Modified Eagle Medium $(\alpha-$ MEM), and DMEM/F-12 medium was acquired from Invitrogen (Carlsbad, CA, USA). Fetal bovine serum (FBS) and penicillin-streptomycin were purchased from Thermo Fisher Scientific (Burlington, ON, Canada). The TRAP staining kit, RA, luteolin, and apigenin were purchased from Sigma-Aldrich (St. Louis, MO, USA). Specific antibodies and goat 
anti-rabbit IgG horseradish peroxidase (HRP) secondary antibodies were obtained from Cell Signaling Technology (Danvers, MA, USA).

\subsection{Preparation of Perilla Leaf Hexane Fraction (PLH)}

Perilla leaves were collected from the Wiang-Sa district, Nan province, Thailand. The voucher specimen code is QSBG-K2, prepared by K. Pintha and P. Tantipaiboonwong, and was certified by the Queen Sirikit Botanic Garden Herbarium, Chiang Mai, Thailand.

The ethanolic crude extract of perilla leaf (LE) was fractionated with hexane and solvent was removed under reduced pressure and then lyophilized to obtain perilla leaf hexane fraction (PLH). The dried fraction was stored at $20^{\circ} \mathrm{C}$ and suspended in dimethyl sulfoxide (DMSO) before use.

\subsection{Chromatographic Analysis for Phenolic and Flavonoid Compounds}

A reversed-phase HPLC, Agilent 1200, equipped with the multi-wavelength and fluorescence detectors, was used to separate, identify, and quantify phenolic and flavonoid compounds as previously described [26]. The assay was carried out using a SymmetryShield ${ }^{\circledR}$ RP18 column $(4.6 \mathrm{~mm} \times 250 \mathrm{~mm}, 5 \mu \mathrm{m}$ particle diameters, Waters Co., Ltd., Milford, MA, USA). The mobile phase consisted of $30 \%$ acetonitrile in $0.1 \%$ acetic acid and de-ionized water at a flow rate of $1.0 \mathrm{~mL} / \mathrm{min}$. The content peaks were detected using a UV detector at $325 \mathrm{~nm}$. The amounts of each detected compound in the samples were calculated and expressed as $\mathrm{mg} / \mathrm{g}$ extract.

\subsection{Cell Cultures}

Mouse macrophage cell line RAW 264.7, human osteoblast-like MG-63 cells, and human osteoblast-like SAOS-2 cells were obtained from American Type Culture Collection (Manassas, VA, USA). RAW 264.7 and MG-63 cells were cultured in DMEM containing $10 \%$ heat-inactivated FBS and $100 \mathrm{U} / \mathrm{mL}$ penicillin-streptomycin under $5 \% \mathrm{CO}_{2}$ at $37^{\circ} \mathrm{C}$. SAOS-2 cell were cultured in DMEM/F-12 containing 10\% heat-inactivated FBS and $100 \mathrm{U} / \mathrm{mL}$ penicillin-streptomycin under $5 \% \mathrm{CO}_{2}$ at $37^{\circ} \mathrm{C}$.

\subsection{Cell Viability Assay}

Cell viability was measured by MTT assays as previously described [97], with slight modifications. In brief, the cells were cultured in a 96-well plate with a density of $5 \times 10^{3}$ cells/well. Then, the cells were cultured with various concentrations of PLH $(0-100 \mu \mathrm{g} / \mathrm{mL})$ for $48 \mathrm{~h}$. Thereafter, MTT was added to each well and incubated at $37^{\circ} \mathrm{C}$ for $4 \mathrm{~h}$. The medium was then removed. DMSO was added to each well, and the color intensity was measured at 540 and $630 \mathrm{~nm}$ using a Cytation 5 multi-mode microplate reader and Gen5 software (Agilent, Santa Clara, CA, USA).

\subsection{Measurement of Intracellular ROS}

The inhibitory effect of PLH on intracellular ROS production was investigated through the measurement of the oxidation of $2^{\prime}, 7^{\prime}$-dichlorodihydrofluorescein diacetate (DCFHDA) to fluorescent $2^{\prime}, 7^{\prime}$-dichlorofluorescein (DCF) as previously described $[98,99]$, with slight modifications. RAW264.7 cells $\left(1 \times 10^{4}\right.$ cells $\left./ \mathrm{mL}\right)$ were cultured in a 96-well culture plate and pre-treated with $0-50 \mu \mathrm{g} / \mathrm{mL}$ of the fraction for $1 \mathrm{~h}$, followed by treatment with $100 \mathrm{ng} / \mathrm{mL}$ RANKL for $1 \mathrm{~h}$. Then, $40 \mu \mathrm{M}$ of DCFH-DA solution was added. Following incubation at $37^{\circ} \mathrm{C}$ and $5 \% \mathrm{CO}_{2}$ for $30 \mathrm{~min}$, the green fluorescence intensity was measured by fluorescent microplate reader at excitation and emission wavelengths of 480 and $525 \mathrm{~nm}$, respectively. $\mathrm{N}$-acetyl cysteine $(80 \mu \mathrm{M})$ and vitamin $\mathrm{C}(250 \mu \mathrm{M})$ were used as positive antioxidant controls. 


\subsection{Differentiation of RAW 264.7 Cells into Osteoclast-like Cells}

RAW264.7 cells were differentiated into osteoclasts by RANKL. RAW 264.7 cells $\left(5.0 \times 10^{3}\right.$ cells / well $)$ were seeded into a 96-well plate with a DMEM culture medium for $24 \mathrm{~h}$. Then, the medium was replaced with a differentiation medium ( $\alpha$-MEM) containing $100 \mathrm{ng} / \mathrm{mL}$ RANKL and the samples (PLH, luteolin, and baicalein) for 6 days, with a replacement of fresh medium every 3 days. Osteoclasts were stained for TRAP using a commercial leukocyte acid phosphatase kit (Sigma-Aldrich, St. Louis, MO, USA) following the manufacturer's protocol. The TRAP-positive cells with three or more nuclei were counted as osteoclasts and visualized under an inverted microscope (Olympus, Tokyo, Japan) [26].

\subsection{Tartrate-Resistant Acid Phosphatase (TRAP) Activity Assay}

Colorimetric analysis for TRAP activity was based on the ability of the phosphatases to catalyze the hydrolysis of the $p$-nitrophenyl phosphate ( $p$-NPP) to a chromogenic product, $p$-nitrophenol ( $p$-NP), with absorbance at $405 \mathrm{~nm}$. The assay was measured as previously defined [26], with some modifications. Briefly, the treated cells were lysed with $0.1 \%$ Triton $\mathrm{X}-100$ and incubated for more than $2 \mathrm{~h}$ at $-80{ }^{\circ} \mathrm{C}$. The lysate was defrosted at $37^{\circ} \mathrm{C}$. Subsequently, $25 \mu \mathrm{L}$ of the substrate solution ( $1 \mathrm{mg} / \mathrm{mL}$ PNPP) was added to $25 \mu \mathrm{L}$ of the lysate and incubated for $4 \mathrm{~h}$ at $37^{\circ} \mathrm{C}$. The reaction was stopped with $50 \mu \mathrm{L}$ of $0.5 \mathrm{M} \mathrm{NaOH}$, and the absorbance was measured at $405 \mathrm{~nm}$ with a microplate reader. $p$-NP was used as a standard.

\subsection{Determination of Matrix Metalloproteinase-9 (MMP-9) Activity}

MMP activity in cell culture supernatants was measured using gelatin zymography as previously described [100], with slight modifications. Culture supernatants were subjected to electrophoresis in a $10 \%$ polyacrylamide gel containing $1 \%$ gelatin. After electrophoresis, gels were soaked in $2.5 \% \mathrm{v} / \mathrm{v}$ Triton X-100 for $30 \mathrm{~min}, 2$ times, and then they were incubated at $37^{\circ} \mathrm{C}$ and kept in an activating buffer $\left(50 \mathrm{mM}\right.$ Tris- $\mathrm{HCl}, 200 \mathrm{mM} \mathrm{NaCl}$, and $10 \mathrm{mM} \mathrm{CaCl}_{2}$ ) at $\mathrm{pH} 7.4$ for $48 \mathrm{~h}$. Bands were stained with Coomassie Brilliant Blue $\mathrm{R}$ and de-stained for $2 \mathrm{~h}$ at room temperature in a solution (10\% acetic acid in 30\% methanol). Images were taken using a Bio-Rad Gel Doc XR system (Hercules, CA, USA). Clear bands corresponding to gelatinolytic activity were quantitated using ImageJ software (NIH).

\subsection{Western Blotting Analysis}

RAW264.7 cells $\left(1 \times 10^{6}\right.$ cells/well $)$ were cultured in a 12-well plate, pretreated with various concentrations of PLH $(0-50 \mu \mathrm{g} / \mathrm{mL})$ for $12 \mathrm{~h}$, and stimulated with RANKL $(100 \mathrm{ng} / \mathrm{mL})$ for $10 \mathrm{~min}$. Whole cell extracts were prepared with RIPA lysis buffer. Nuclear fractions were prepared using the nuclear extraction buffer. Protein concentration was determined using the Bradford Protein Assay Kit (Bio Basic Inc., Markham, ON, Canada). Equal amounts of protein were subjected to sodium dodecyl sulfate polyacrylamide gel electrophoresis (SDS-PAGE), followed by transfer to nitrocellulose membranes. After blocking with $5 \%$ BSA, the bands were probed with specific primary antibodies and incubated at $4{ }^{\circ} \mathrm{C}$ overnight. HRP-conjugated secondary antibodies were then added. After incubation, the targeted proteins were visualized by enhanced chemiluminescence (ECL) reagents (Bio-Rad, Hercules, CA, USA). Images were exposed to the X-ray film (GE Healthcare Ltd., Chicago, IL, USA). PARP and $\beta$-actin were used as the internal reference.

\subsection{Alkaline Phosphatase (ALP) Activity Assay}

Osteogenic potential has been studied using osteoblast-like cell lines, including MG-63 and SAOS-2 cells [101,102]. ALP activity was measured via the hydrolysis of $p$-NPP. After treating the cells for $72 \mathrm{~h}, 0.1 \%$ Triton $\mathrm{X}-100$ was added to each well and incubated for more than $2 \mathrm{~h}$ at $-80^{\circ} \mathrm{C}$. The lysate was defrosted at $37^{\circ} \mathrm{C}$. Then, $25 \mu \mathrm{L}$ of the substrate solution $\left(1 \mathrm{mg} / \mathrm{mL} p\right.$-PNPP) was added to $25 \mu \mathrm{L}$ of the lysate and incubated for $4 \mathrm{~h}$ at $37^{\circ} \mathrm{C}$. The 
reaction was stopped with $50 \mu \mathrm{L}$ of $0.5 \mathrm{M} \mathrm{NaOH}$ and the absorbance was measured at $405 \mathrm{~nm}$ with a microplate reader. $p$-NP was used as a standard.

\subsection{Statistical Analysis}

All experiments were performed in triplicate and data are presented as mean \pm standard deviation (SD). The results were statistically analyzed using GraphPad Prism 9 Software (La Jolla, CA, USA). \# $p<0.05$, \#\# $p<0.01$, and \#\#\# $p<0.001$ vs. control and ${ }^{*} p<0.05,{ }^{* *} p<0.01$, and ${ }^{* * *} p<0.001$ vs. RANKL or TNF- $\alpha$ treatment were used as the significant difference.

\section{Conclusions}

This is a unique report, because it shows the effects of luteolin- and baicalein-rich PLH on bone resorption and formation. We demonstrated that PLH regulates osteoclast by blocking RANKL-induced ROS production, NF-kB, MAPK phosphorylation, NFATc1 expression, TRAP activity, and MMP-9 secretion. PLH also promotes the function of osteoblasts by increasing ALP activity and restoring TNF- $\alpha$-suppressed osteogenic potential. Therefore, PLH-targeting treatments for osteoporosis not only suppressed bone resorption but also promoted bone formation. It can be suggested that PLH might be a potential preventive and therapeutic agent for osteoporosis disease. Further studies will be required to confirm the efficacy of PLH in treating bone disease conditions. Such studies should employ a broader physiopathological framework for analysis of the intracellular pathways of osteogenic molecules in vivo and be carried out in a clinical setting.

Author Contributions: K.P. (Kanokkarn Phromnoi), M.S., C.S. and P.D. designed the study; K.P. (Kanokkarn Phromnoi), S.Y., K.P. (Komsak Pintha), S.M. and C.S. performed the experiments; K.P. (Kanokkarn Phromnoi), C.S. and S.M. analyzed the data; and K.P. (Kanokkarn Phromnoi), M.S., S.Y., C.S. and P.D. wrote, reviewed, and edited the manuscript. All authors have read and agreed to the published version of the manuscript.

Funding: This research was funded by the Thailand Science Research and Innovation fund and the University of Phayao (Grant No. FF64-UoE043 and FF65-RIM108).

Institutional Review Board Statement: Not applicable.

Informed Consent Statement: Not applicable.

Data Availability Statement: Not applicable.

Acknowledgments: This research is partially supported by Chiang Mai University, the Center for Research and Development of Natural Products for Health, the Faculty of Medicine and Faculty of Pharmacy, Chiang Mai University, and University of Phayao, Thailand.

Conflicts of Interest: The authors declare no conflict of interest.

Sample Availability: Samples of the luteolin- and baicalein-rich perilla leaf hexane fraction (PLH) are not available from the authors.

\section{References}

1. Feng, X.; McDonald, J.M. Disorders of bone remodeling. Annu. Rev. Pathol. 2011, 6, 121-145. [CrossRef] [PubMed]

2. Rodan, G.A.; Martin, T.J. Therapeutic approaches to bone diseases. Science 2000, 289, 1508-1514. [CrossRef] [PubMed]

3. Colon-Emeric, C.S.; Saag, K.G. Osteoporotic fractures in older adults. Best Pract. Res. Clin. Rheumatol. 2006, 20, 695-706. [CrossRef] [PubMed]

4. Giannoudis, P.V.; Einhorn, T.A.; Marsh, D. Fracture healing: The diamond concept. Injury 2007, 38 (Suppl. S4), S3-S6. [CrossRef]

5. Raisz, L.G. Pathogenesis of osteoporosis: Concepts, conflicts, and prospects. J. Clin. Investig. 2005, 115, 3318-3325. [CrossRef]

6. Martiniakova, M.; Babikova, M.; Omelka, R. Pharmacological agents and natural compounds: Available treatments for osteoporosis. J. Physiol. Pharmacol. 2020, 71, 207-320. [CrossRef]

7. Pang, R.; Xia, W. Pharmacological Treatment of Bone Loss. Curr. Pharm. Des. 2017, 23, 6298-6301. [CrossRef]

8. Miller, P.D. Denosumab: Anti-RANKL antibody. Curr. Osteoporos Rep. 2009, 7, 18-22. [CrossRef]

9. Haas, A.V.; LeBoff, M.S. Osteoanabolic Agents for Osteoporosis. J. Endocr. Soc. 2018, 2, 922-932. [CrossRef]

10. He, J.; Li, X.; Wang, Z.; Bennett, S.; Chen, K.; Xiao, Z.; Zhan, J.; Chen, S.; Hou, Y.; Chen, J.; et al. Therapeutic Anabolic and Anticatabolic Benefits of Natural Chinese Medicines for the Treatment of Osteoporosis. Front. Pharmacol. 2019, 10, 1-23. [CrossRef] 
11. Tabacco, G.; Bilezikian, J.P. Osteoanabolic and dual action drugs. Br. J. Clin. Pharmacol. 2019, 85, 1084-1094. [CrossRef]

12. Li, H.; Xiao, Z.; Quarles, L.D.; Li, W. Osteoporosis: Mechanism, Molecular Target and Current Status on Drug Development. Curr. Med. Chem. 2021, 28, 1489-1507. [CrossRef] [PubMed]

13. Hofbauer, L.C.; Heufelder, A.E. Clinical review 114: Hot topic. The role of receptor activator of nuclear factor-kappaB ligand and osteoprotegerin in the pathogenesis and treatment of metabolic bone diseases. J. Clin. Endocrinol. Metab. 2000, 85, $2355-2363$. [CrossRef] [PubMed]

14. Walsh, M.C.; Kim, N.; Kadono, Y.; Rho, J.; Lee, S.Y.; Lorenzo, J.; Choi, Y. Osteoimmunology: Interplay between the immune system and bone metabolism. Annu. Rev. Immunol. 2006, 24, 33-63. [CrossRef] [PubMed]

15. Alexander, C.M.; Hansell, E.J.; Behrendtsen, O.; Flannery, M.L.; Kishnani, N.S.; Hawkes, S.P.; Werb, Z. Expression and function of matrix metalloproteinases and their inhibitors at the maternal-embryonic boundary during mouse embryo implantation. Development 1996, 122, 1723-1736. [CrossRef] [PubMed]

16. Reponen, P.; Sahlberg, C.; Munaut, C.; Thesleff, I.; Tryggvason, K. High expression of 92-kDa type IV collagenase (gelatinase) in the osteoclast lineage during mouse development. Ann. N. Y. Acad. Sci. 1994, 732, 472-475. [CrossRef] [PubMed]

17. Liu, T.; Gao, Y.; Sakamoto, K.; Minamizato, T.; Furukawa, K.; Tsukazaki, T.; Shibata, Y.; Bessho, K.; Komori, T.; Yamaguchi, A. BMP-2 promotes differentiation of osteoblasts and chondroblasts in Runx2-deficient cell lines. J. Cell. Physiol. 2007, 211, 728-735. [CrossRef]

18. Barthelemi, S.; Robinet, J.; Garnotel, R.; Antonicelli, F.; Schittly, E.; Hornebeck, W.; Lorimier, S. Mechanical forces-induced human osteoblasts differentiation involves MMP-2/MMP-13/MT1-MMP proteolytic cascade. J. Cell. Biochem. 2012, 113, 760-772. [CrossRef]

19. Matos, A.A.; Oliveira, F.A.; Machado, A.C.; Saldanha, L.L.; Tokuhara, C.K.; Souza, L.P.; Vilegas, W.; Dionisio, T.J.; Santos, C.; Peres-Buzalaf, C.; et al. An extract from Myracrodruon urundeuva inhibits matrix mineralization in human osteoblasts. J. Ethnopharmacol. 2019, 237, 192-201. [CrossRef]

20. Slompo, C.; Buzalaf, C.P.; Damante, C.A.; Martins, G.M.; Hannas, A.R.; Buzalaf, M.A.; Oliveira, R.C. Fluoride modulates preosteoblasts viability and matrix metalloproteinases-2 and -9 activities. Braz. Dent. J. 2012, 23, 629-634. [CrossRef]

21. Kim, I.; Kim, J.H.; Kim, K.; Seong, S.; Kim, N. The IRF2BP2-KLF2 axis regulates osteoclast and osteoblast differentiation. BMB Rep. 2019, 52, 469-474. [CrossRef]

22. Pivodova, V.; Frankova, J.; Dolezel, P.; Ulrichova, J. The response of osteoblast-like SaOS-2 cells to modified titanium surfaces. Int. J. Oral Maxillofac. Implants 2013, 28, 1386-1394. [CrossRef] [PubMed]

23. Makras, P.; Athanasakis, K.; Boubouchairopoulou, N.; Rizou, S.; Anastasilakis, A.D.; Kyriopoulos, J.; Lyritis, G.P. Cost-effective osteoporosis treatment thresholds in Greece. Osteoporos. Int. 2015, 26, 1949-1957. [CrossRef] [PubMed]

24. Urasopon, N.; Hamada, Y.; Asaoka, K.; Cherdshewasart, W.; Malaivijitnond, S. Pueraria mirifica, a phytoestrogen-rich herb, prevents bone loss in orchidectomized rats. Maturitas 2007, 56, 322-331. [CrossRef] [PubMed]

25. Wanachewin, O.; Pothacharoen, P.; Kongtawelert, P.; Phitak, T. Inhibitory effects of sesamin on human osteoclastogenesis. Arch. Pharm. Res. 2017, 40, 1186-1196. [CrossRef]

26. Phromnoi, K.; Suttajit, M.; Saenjum, C.; Limtrakul Dejkriengkraikul, P. Inhibitory Effect of a Rosmarinic Acid-Enriched Fraction Prepared from Nga-Mon (Perilla frutescens) Seed Meal on Osteoclastogenesis through the RANK Signaling Pathway. Antioxidants 2021, 10, 307. [CrossRef]

27. Siriamornpun, S.; Li, D.; Yang, L.; Suttajit, S.; Suttajit, M. Variation of lipid and fatty acid compositions in Thai Perilla seeds grown at different locations. Songklanakarin J. Sci. Technol. 2006, 28, 17-21.

28. Ahmed, H.M. Ethnomedicinal, Phytochemical and Pharmacological Investigations of Perilla frutescens (L.) Britt. Molecules 2018, 24, 102. [CrossRef]

29. Asif, M. Health effects of omega-3,6,9 fatty acids: Perilla frutescens is a good example of plant oils. Orient. Pharm. Exp. Med. 2011, 11, 51-59. [CrossRef]

30. Asif, M. Phytochemical study of polyphenols in Perilla Frutescens as an antioxidant. Avicenna J. Phytomed. 2012, 2, 169-178.

31. Muller-Waldeck, F.; Sitzmann, J.; Schnitzler, W.H.; Grassmann, J. Determination of toxic perilla ketone, secondary plant metabolites and antioxidative capacity in five Perilla frutescens L. varieties. Food Chem. Toxicol. 2010, 48, 264-270. [CrossRef] [PubMed]

32. Phromnoi, K.; Suttajit, M.; Saenjum, C. Polyphenols and rosmarinic acid contents, antioxidant and anti-inflammatory activities of different solvent fractions from Nga-Mon (Perilla frutescens) leaf. J. Pharm. Nutr. Sci. 2019, 9, 239-246. [CrossRef]

33. Pintha, K.; Tantipaiboonwong, P.; Yodkeeree, S.; Chaiwangyen, W.; Chumphukam, O.; Khantamat, O.; Khanaree, C.; Kangwan, N.; Thongchuai, B.; Suttajit, M. Thai perilla (Perilla frutescens) leaf extract inhibits human breast cancer invasion and migration. Maejo Int. J. Sci. Technol. 2018, 12, 112-123.

34. Khanaree, C.; Pintha, K.; Tantipaiboonwong, P.; Suttajit, M.; Chewonarin, T. The effect of Perilla frutescens leaf on 1, 2dimethylhydrazine-induced initiation of colon carcinogenesis in rats. J. Food Biochem. 2018, 42, e12493. [CrossRef]

35. Zhu, F.; Asada, T.; Sato, A.; Koi, Y.; Nishiwaki, H.; Tamura, H. Rosmarinic acid extract for antioxidant, antiallergic, and alphaglucosidase inhibitory activities, isolated by supramolecular technique and solvent extraction from Perilla leaves. J. Agric. Food Chem. 2014, 62, 885-892. [CrossRef] [PubMed]

36. Bassoli, A.; Borgonovo, G.; Morini, G.; De Petrocellis, L.; Schiano Moriello, A.; Di Marzo, V. Analogues of perillaketone as highly potent agonists of TRPA1 channel. Food Chem. 2013, 141, 2044-2051. [CrossRef] [PubMed] 
37. Bachheti, R.; Joshi, A.; Ahmed, T. A phytopharmacological overview on Perilla frutescens. Int. J. Pharm. Sci. Rev. Res. 2014, 26, 55-61.

38. Meng, L.; Lozano, Y.; Bombarda, I.; Gaydou, E.M.; Li, B. Polyphenol extraction from eight Perilla frutescens cultivars. Comptes R. Chim. 2009, 12, 602-611. [CrossRef]

39. Weaver, C.M.; Alekel, D.L.; Ward, W.E.; Ronis, M.J. Flavonoid intake and bone health. J. Nutr. Gerontol. Geriatr. 2012, 31, $239-253$. [CrossRef]

40. Lee, J.W.; Ahn, J.Y.; Hasegawa, S.; Cha, B.Y.; Yonezawa, T.; Nagai, K.; Seo, H.J.; Jeon, W.B.; Woo, J.T. Inhibitory effect of luteolin on osteoclast differentiation and function. Cytotechnology 2009, 61, 125-134. [CrossRef]

41. Jing, Z.; Wang, C.; Yang, Q.; Wei, X.; Jin, Y.; Meng, Q.; Liu, Q.; Liu, Z.; Ma, X.; Liu, K.; et al. Luteolin attenuates glucocorticoidinduced osteoporosis by regulating ERK/Lrp-5/GSK-3beta signaling pathway in vivo and in vitro. J. Cell. Physiol. 2019, 234, 4472-4490. [CrossRef]

42. Yun, J.K.; Cheon, Y.-H.; Kim, J.-Y.; Kwak, S.C.; Yoon, K.H.; Baek, J.M.; Lee, M.S.; Oh, J.; Park, J. The Effects of Baicalein on Osteoclast Differentiation from Bone Marrow Derived Macrophage. Korean J. Phys. Anthropol. 2014, 27, 91-99. [CrossRef]

43. Kim, J.M.; Lee, S.U.; Kim, Y.S.; Min, Y.K.; Kim, S.H. Baicalein stimulates osteoblast differentiation via coordinating activation of MAP kinases and transcription factors. J. Cell. Biochem. 2008, 104, 1906-1917. [CrossRef] [PubMed]

44. Kong, L.; Smith, W.; Hao, D. Overview of RAW264.7 for osteoclastogensis study: Phenotype and stimuli. J. Cell Mol. Med. 2019, 23, 3077-3087. [CrossRef] [PubMed]

45. Nguyen, J.; Nohe, A. Factors that affect the osteoclastogenesis of RAW264. 7 cells. J. Biochem. Anal. Stud. 2017, 2, 1-7. [CrossRef]

46. Bezerra, D.P.; Militao, G.C.G.; de Morais, M.C.; de Sousa, D.P. The Dual Antioxidant/Prooxidant Effect of Eugenol and Its Action in Cancer Development and Treatment. Nutrients 2017, 9, 1367. [CrossRef] [PubMed]

47. Tothova, L.; Celec, P. Oxidative Stress and Antioxidants in the Diagnosis and Therapy of Periodontitis. Front. Physiol. 2017, 8, 1055. [CrossRef] [PubMed]

48. Paiva, K.B.; Granjeiro, J.M. Bone tissue remodeling and development: Focus on matrix metalloproteinase functions. Arch. Biochem. Biophys. 2014, 561, 74-87. [CrossRef]

49. Teitelbaum, S.L.; Ross, F.P. Genetic regulation of osteoclast development and function. Nat. Rev. Genet. 2003, 4, 638-649. [CrossRef]

50. Ohshiba, T.; Miyaura, C.; Inada, M.; Ito, A. Role of RANKL-induced osteoclast formation and MMP-dependent matrix degradation in bone destruction by breast cancer metastasis. Br. J. Cancer 2003, 88, 1318-1326. [CrossRef]

51. Kusano, K.; Miyaura, C.; Inada, M.; Tamura, T.; Ito, A.; Nagase, H.; Kamoi, K.; Suda, T. Regulation of matrix metalloproteinases (MMP-2, -3, -9, and -13) by interleukin-1 and interleukin-6 in mouse calvaria: Association of MMP induction with bone resorption. Endocrinology 1998, 139, 1338-1345. [CrossRef] [PubMed]

52. Franco, G.C.; Kajiya, M.; Nakanishi, T.; Ohta, K.; Rosalen, P.L.; Groppo, F.C.; Ernst, C.W.; Boyesen, J.L.; Bartlett, J.D.; Stashenko, P.; et al. Inhibition of matrix metalloproteinase- 9 activity by doxycycline ameliorates RANK ligand-induced osteoclast differentiation in vitro and in vivo. Exp. Cell Res. 2011, 317, 1454-1464. [CrossRef]

53. Xu, H.; Liu, T.; Li, J.; Xu, J.; Chen, F.; Hu, L.; Zhang, B.; Zi, C.; Wang, X.; Sheng, J. Oxidation derivative of (-)-epigallocatechin3-gallate (EGCG) inhibits RANKL-induced osteoclastogenesis by suppressing RANK signaling pathways in RAW 264.7 cells. Biomed. Pharmacother. 2019, 118, 9237. [CrossRef] [PubMed]

54. Boyce, B.F.; Xiu, Y.; Li, J.; Xing, L.; Yao, Z. NF-кB-Mediated Regulation of Osteoclastogenesis. Endocrinol. Metab. 2015, 30, 35-44. [CrossRef]

55. Chen, Y.J.; Bai, L.; Wu, J.Y.; Liu, Y.X.; Fu, X.Q.; Zhu, P.L.; Li, J.K.; Yin, C.L.; Chou, J.Y.; Wang, Y.P.; et al. A two-herb formula inhibits osteoclastogenesis and suppresses NF-кB and MAPK pathways. J. Ethnopharmacol. 2020, 252, 112625. [CrossRef] [PubMed]

56. Jimi, E.; Aoki, K.; Saito, H.; D’Acquisto, F.; May, M.J.; Nakamura, I.; Sudo, T.; Kojima, T.; Okamoto, F.; Fukushima, H.; et al. Selective inhibition of NF- $\mathrm{KB}$ blocks osteoclastogenesis and prevents inflammatory bone destruction in vivo. Nat. Med. 2004, 10, 617-624. [CrossRef] [PubMed]

57. Li, Z.; Chen, C.; Zhu, X.; Li, Y.; Yu, R.; Xu, W. Glycyrrhizin Suppresses RANKL-Induced Osteoclastogenesis and Oxidative Stress Through Inhibiting NF-kB and MAPK and Activating AMPK/Nrf2. Calcif. Tissue Int. 2018, 103, 324-337. [CrossRef]

58. Kim, J.H.; Kim, N. Signaling pathways in osteoclast differentiation. Chonnam Med. J. 2016, 52, 12-17. [CrossRef]

59. Rodan, S.B.; Imai, Y.; Thiede, M.A.; Wesolowski, G.; Thompson, D.; Bar-Shavit, Z.; Shull, S.; Mann, K.; Rodan, G.A. Characterization of a human osteosarcoma cell line (Saos-2) with osteoblastic properties. Cancer Res. 1987, 47, 4961-4966.

60. Prideaux, M.; Wijenayaka, A.R.; Kumarasinghe, D.D.; Ormsby, R.T.; Evdokiou, A.; Findlay, D.M.; Atkins, G.J. SaOS2 osteosarcoma cells as an in vitro model for studying the transition of human osteoblasts to osteocytes. Calcif. Tissue Int. 2014, 95, 183-193. [CrossRef] [PubMed]

61. Fan, J.; Yang, X.; Bi, Z. The effects of 6-gingerol on proliferation, differentiation, and maturation of osteoblast-like MG-63 cells Braz. J. Med. Biol. Res. 2015, 48, 637-643. [CrossRef] [PubMed]

62. Vandrovcova, M.; Jirka, I.; Novotna, K.; Lisa, V.; Frank, O.; Kolska, Z.; Stary, V.; Bacakova, L. Interaction of human osteoblast-like Saos-2 and MG-63 cells with thermally oxidized surfaces of a titanium-niobium alloy. PLoS ONE 2014, 9, e100475. [CrossRef] [PubMed]

63. Taichman, R.S.; Emerson, S.G. Human osteosarcoma cell lines MG-63 and SaOS-2 produce G-CSF and GM-CSF: Identification and partial characterization of cell-associated isoforms. Exp. Hematol. 1996, 24, 509-517. 
64. Chaturvedi, R.; Singha, P.K.; Dey, S. Water soluble bioactives of nacre mediate antioxidant activity and osteoblast differentiation. PLoS ONE 2013, 8, e84584. [CrossRef] [PubMed]

65. Szulc, P.; Bauer, D.C.; Eastell, R. Biochemical markers of bone turnover in osteoporosis. In Marcus and Feldman's Osteoporosis; Elsevier: Amsterdam, The Netherlands, 2021; pp. 1545-1588.

66. Feng, P.; Zhang, H.; Zhang, Z.; Dai, X.; Mao, T.; Fan, Y.; Xie, X.; Wen, H.; Yu, P.; Hu, Y.; et al. The interaction of MMP-2/B7-H3 in human osteoporosis. Clin. Immunol. 2016, 162, 118-124. [CrossRef] [PubMed]

67. Kuno, K.; Sukegawa, K.; Ishikawa, Y.; Orii, T.; Matsushima, K. Acid sphingomyelinase is not essential for the IL-1 and tumor necrosis factor receptor signaling pathway leading to NFkB activation. Int. Immunol. 1994, 6, 1269-1272. [CrossRef]

68. Gilbert, L.; He, X.; Farmer, P.; Boden, S.; Kozlowski, M.; Rubin, J.; Nanes, M.S. Inhibition of osteoblast differentiation by tumor necrosis factor-alpha. Endocrinology 2000, 141, 3956-3964. [CrossRef] [PubMed]

69. Gilbert, L.; He, X.; Farmer, P.; Rubin, J.; Drissi, H.; van Wijnen, A.J.; Lian, J.B.; Stein, G.S.; Nanes, M.S. Expression of the osteoblast differentiation factor RUNX2 (Cbfa1/AML3/Pebp2 $\alpha$ A) is inhibited by tumor necrosis factor- $\alpha$. J. Biol. Chem. 2002, 277, $2695-2701$. [CrossRef]

70. Demontiero, O.; Vidal, C.; Duque, G. Aging and bone loss: New insights for the clinician. Ther. Adv. Musculoskelet. Dis. 2012, 4, 61-76. [CrossRef]

71. Wang, Z.; Tu, Z.; Xie, X.; Cui, H.; Kong, K.W.; Zhang, L. Perilla frutescens Leaf Extract and Fractions: Polyphenol Composition, Antioxidant, Enzymes ( $\alpha$-Glucosidase, Acetylcholinesterase, and Tyrosinase) Inhibitory, Anticancer, and Antidiabetic Activities. Foods 2021, 10, 315. [CrossRef]

72. Jia, L.; Shi, L.; Li, J.; Zeng, Y.; Tang, S.; Liu, W.; Mo, X.; Liu, X. Total flavonoids from celery suppresses RANKL-induced osteoclast differentiation and bone resorption function via attenuating NF-kB and p38 pathways in RAW264. 7 cells. J. Funct. Foods 2020, 69, 103949. [CrossRef]

73. Yan, Z.; Zhan, J.; Qi, W.; Lin, J.; Huang, Y.; Xue, X.; Pan, X. The Protective Effect of Luteolin in Glucocorticoid-Induced Osteonecrosis of the Femoral Head. Front. Pharmacol. 2020, 11, 1195. [CrossRef]

74. Lu, X.; He, W.; Yang, W.; Li, J.; Han, W.; Liu, Q.; Zhang, T.; Jiang, J.; Qin, A.; Qian, Y. Dual effects of baicalin on osteoclast differentiation and bone resorption. J. Cell Mol. Med. 2018, 22, 5029-5039. [CrossRef]

75. Li, S.F.; Tang, J.J.; Chen, J.; Zhang, P.; Wang, T.; Chen, T.Y.; Yan, B.; Huang, B.; Wang, L.; Huang, M.J.; et al. Regulation of bone formation by baicalein via the mTORC1 pathway. Drug Des. Dev. Ther. 2015, 9, 5169-5183. [CrossRef]

76. Jules, J.; Ashley, J.W.; Feng, X. Selective targeting of RANK signaling pathways as new therapeutic strategies for osteoporosis. Expert. Opin. Ther. Targets 2010, 14, 923-934. [CrossRef] [PubMed]

77. Agidigbi, T.S.; Kim, C. Reactive Oxygen Species in Osteoclast Differentiation and Possible Pharmaceutical Targets of ROSMediated Osteoclast Diseases. Int. J. Mol. Sci. 2019, 20, 43576. [CrossRef] [PubMed]

78. Motohashi, N.; Kawase, M.; Saito, S.; Kurihara, T.; Satoh, K.; Nakashima, H.; Premanathan, M.; Arakaki, R.; Sakagami, H.; Molnar J. Synthesis and biological activity of $\mathrm{N}$-acylphenothiazines. Int. J. Antimicrob. Agents 2000, 14, 203-207. [CrossRef]

79. Adomako-Bonsu, A.G.; Chan, S.L.; Pratten, M.; Fry, J.R. Antioxidant activity of rosmarinic acid and its principal metabolites in chemical and cellular systems: Importance of physico-chemical characteristics. Toxicol. In Vitro 2017, 40, 248-255. [CrossRef] [PubMed]

80. Cheng, C.; Wentworth, K.; Shoback, D.M. New Frontiers in Osteoporosis Therapy. Annu. Rev. Med. 2020, 71, 277-288. [CrossRef]

81. Hayman, A.R. Tartrate-resistant acid phosphatase (TRAP) and the osteoclast/immune cell dichotomy. Autoimmunity 2008, 41, 218-223. [CrossRef]

82. Logar, D.B.; Komadina, R.; Prezelj, J.; Ostanek, B.; Trost, Z.; Marc, J. Expression of bone resorption genes in osteoarthritis and in osteoporosis. J. Bone Miner. Metab. 2007, 25, 219-225. [CrossRef]

83. Kobayashi, N.; Kadono, Y.; Naito, A.; Matsumoto, K.; Yamamoto, T.; Tanaka, S.; Inoue, J. Segregation of TRAF6-mediated signaling pathways clarifies its role in osteoclastogenesis. EMBO J. 2001, 20, 1271-1280. [CrossRef]

84. Mizukami, J.; Takaesu, G.; Akatsuka, H.; Sakurai, H.; Ninomiya-Tsuji, J.; Matsumoto, K.; Sakurai, N. Receptor activator of NF-kB ligand (RANKL) activates TAK1 mitogen-activated protein kinase kinase kinase through a signaling complex containing RANK, TAB2, and TRAF6. Mol. Cell. Biol. 2002, 22, 992-1000. [CrossRef] [PubMed]

85. Hsiao, Y.-m.; Hu, C.-C.; Chen, M.-F.; Chang, C.-H.; Chiu, Y.-T.; Chang, Y. Serum Insufficiency Induces RANKL-Independent Osteoclast Formation during Developing Ischemic ONFH. Biomedicines 2021, 9, 685. [CrossRef] [PubMed]

86. Li, X.; Udagawa, N.; Itoh, K.; Suda, K.; Murase, Y.; Nishihara, T.; Suda, T.; Takahashi, N. p38 MAPK-mediated signals are required for inducing osteoclast differentiation but not for osteoclast function. Endocrinology 2002, 143, 3105-3113. [CrossRef] [PubMed]

87. David, J.P.; Sabapathy, K.; Hoffmann, O.; Idarraga, M.H.; Wagner, E.F. JNK1 modulates osteoclastogenesis through both c-Jun phosphorylation-dependent and -independent mechanisms. J. Cell Sci. 2002, 115, 4317-4325. [CrossRef] [PubMed]

88. Matsumoto, M.; Kogawa, M.; Wada, S.; Takayanagi, H.; Tsujimoto, M.; Katayama, S.; Hisatake, K.; Nogi, Y. Essential role of p38 mitogen-activated protein kinase in cathepsin K gene expression during osteoclastogenesis through association of NFATc1 and PU.1. J. Biol. Chem. 2004, 279, 45969-45979. [CrossRef] [PubMed]

89. Chiou, W.F.; Huang, Y.L.; Liu, Y.W. (+)-Vitisin A inhibits osteoclast differentiation by preventing TRAF6 ubiquitination and TRAF6-TAK1 formation to suppress NFATc1 activation. PLoS ONE 2014, 9, 89159. [CrossRef]

90. Shi, Y.; Liu, X.Y.; Jiang, Y.P.; Zhang, J.B.; Zhang, Q.Y.; Wang, N.N.; Xin, H.L. Monotropein attenuates oxidative stress via Akt/mTOR-mediated autophagy in osteoblast cells. Biomed. Pharmacother. 2020, 121, 109566. [CrossRef] 
91. Gao, J.; Feng, Z.; Wang, X.; Zeng, M.; Liu, J.; Han, S.; Xu, J.; Chen, L.; Cao, K.; Long, J. SIRT3/SOD2 maintains osteoblast differentiation and bone formation by regulating mitochondrial stress. Cell Death Differ. 2018, 25, 229-240. [CrossRef]

92. Arakaki, N.; Yamashita, A.; Niimi, S.; Yamazaki, T. Involvement of reactive oxygen species in osteoblastic differentiation of MC3T3-E1 cells accompanied by mitochondrial morphological dynamics. Biomed. Res. 2013, 34, 161-166. [CrossRef] [PubMed]

93. Tao, H.; Ge, G.; Liang, X.; Zhang, W.; Sun, H.; Li, M.; Geng, D. ROS signaling cascades: Dual regulations for osteoclast and osteoblast. Acta Biochim. Biophys. Sin. 2020, 52, 1055-1062. [CrossRef] [PubMed]

94. Houschyar, K.S.; Tapking, C.; Borrelli, M.R.; Popp, D.; Duscher, D.; Maan, Z.N.; Chelliah, M.P.; Li, J.; Harati, K.; Wallner, C.; et al. Wnt Pathway in Bone Repair and Regeneration-What Do We Know So Far. Front. Cell Dev. Biol. 2018, 6, 170. [CrossRef] [PubMed]

95. Kramer, I.; Halleux, C.; Keller, H.; Pegurri, M.; Gooi, J.H.; Weber, P.B.; Feng, J.Q.; Bonewald, L.F.; Kneissel, M. Osteocyte Wnt/ $\beta$-catenin signaling is required for normal bone homeostasis. Mol. Cell. Biol. 2010, 30, 3071-3085. [CrossRef]

96. Cha, P.H.; Shin, W.; Zahoor, M.; Kim, H.Y.; Min do, S.; Choi, K.Y. Hovenia dulcis Thunb extract and its ingredient methyl vanillate activate $\mathrm{Wnt} / \beta$-catenin pathway and increase bone mass in growing or ovariectomized mice. PLoS ONE 2014, 9, 85546. [CrossRef]

97. Lin, C.S.; Kuo, C.L.; Wang, J.P.; Cheng, J.S.; Huang, Z.W.; Chen, C.F. Growth inhibitory and apoptosis inducing effect of Perilla frutescens extract on human hepatoma HepG2 cells. J. Ethnopharmacol. 2007, 112, 557-567. [CrossRef]

98. Amer, J.; Goldfarb, A.; Fibach, E. Flow cytometric analysis of the oxidative status of normal and thalassemic red blood cells. Cytometry A 2004, 60, 73-80. [CrossRef] [PubMed]

99. Banjerdpongchai, R.; Wudtiwai, B.; Khaw-On, P.; Rachakhom, W.; Duangnil, N.; Kongtawelert, P. Hesperidin from Citrus seed induces human hepatocellular carcinoma HepG2 cell apoptosis via both mitochondrial and death receptor pathways. Tumour Biol. 2016, 37, 227-237. [CrossRef]

100. Ooppachai, C.; Limtrakul Dejkriengkraikul, P.; Yodkeeree, S. Dicentrine Potentiates TNF- $\alpha$-Induced Apoptosis and Suppresses Invasion of A549 Lung Adenocarcinoma Cells via Modulation of NF-kB and AP-1 Activation. Molecules 2019, 24, 4100. [CrossRef]

101. Burmester, A.; Luthringer, B.; Willumeit, R.; Feyerabend, F. Comparison of the reaction of bone-derived cells to enhanced $\mathrm{MgCl}_{2}$-salt concentrations. Biomatter 2014, 4, 967616. [CrossRef]

102. Wilkesmann, S.; Fellenberg, J.; Reible, B.; Westhauser, F. Primary osteoblasts, osteoblast precursor cells or osteoblast-like cell lines. J. Biomed. Mater. Res. 2020, 108, 663-674. [CrossRef] [PubMed] 